\title{
Laboratory Experiments on Environmental Friendly Means to Improve Coalbed Methane Production by Carbon Dioxide/Flue Gas Injection
}

\author{
S. Mazumder • K. H. A. A. Wolf • P. van Hemert • \\ A. Busch
}

Received: 22 February 2006 / Accepted: 5 February 2008 / Published online: 3 April 2008

(C) The Author(s) 2008

\begin{abstract}
Scaled in situ laboratory core flooding experiments with $\mathrm{CO}_{2}, \mathrm{~N}_{2}$ and flue gas were carried out on coal in an experimental high P,T device. These experiments will be able to give an insight into the design of the injection system, management, control of the operations and the efficiency of an ECBM project. Although the experience gained by the oil industry represents a valuable starting point, several problems are still to be studied and solved before $\mathrm{CO}_{2}$ improved deep coalbed methane production may be operationally feasible. These are all related to the heterogeneous nature of the pore structure of coal, and in particular to the presence of fractures. More specifically, a number of questions need to be addressed, e.g. what are the conditions under which the fluid in the micro pores of the coal is displaced by the $\mathrm{CO}_{2}$ in the presence of competitive adsorption; what is the role of compositional heterogeneity and fracture anisotropy of coal for the injection design and the efficiency of the sequestration in relation to the swelling and shrinkage characteristics of coal; how does the mobile and the immobile water in the coal affect the exchange process. These questions can be answered by means of downscaled laboratory experiments that are capable of accurately describing the coupled process of multiphase flow, competitive adsorption and geo-mechanics. The laboratory conditions have been simulated to match pressure and temperature at depths of 800 to $1,000 \mathrm{~m}$. Under those conditions the injected $\mathrm{CO}_{2}$ remains supercritical. Upto now, the results show that dewatering will be an essential step for successful ECBM combined with a $\mathrm{CO}_{2}$ sequestration process.
\end{abstract}

S. Mazumder $(\varangle)$

Shell International Exploration and Production B.V., Kesslerpark 1, 2288 GS, Rijswijk, The Netherlands e-mail: saikat.mazumder@shell.com

K. H. A. A. Wolf · P. van Hemert

Department of Geotechnology, Delft University of Technology, Stevinweg 1, 2628 CN, Delft,

The Netherlands

e-mail: K.H.A.A.Wolf@ citg.tudelft.nl

P. van Hemert

e-mail: P.vanHemert@ citg.tudelft.nl

A. Busch

Institute of Geology and Geochemistry of Petroleum and Coal, RWTH Aachen University, Lochnerstr. 4-20, 52056 Aachen, Germany

e-mail: busch@lek.rwth-aachen.de 
Keywords Coal $\cdot$ Enhanced coalbed methane $\cdot$ Flue gas $\cdot$ Preferential sorption

\section{Introduction}

The injection of carbon dioxide $\left(\mathrm{CO}_{2}\right)$, in coalbeds is one of the more attractive options of all underground $\mathrm{CO}_{2}$ storage possibilities: the $\mathrm{CO}_{2}$ is stored combined with simultaneous recovery of coalbed methane (CBM). Among all the fossil fuels, when combusted, methane emits the least amount of $\mathrm{CO}_{2}$ per unit of energy released. Therefore, the zero option of $\mathrm{CO}_{2}$ sequestration and production of methane lead to greater utilization of coalbed resources for both their sequestration ability and energy content. The revenue of methane $\left(\mathrm{CH}_{4}\right)$ production can offset the expenditures of the storage operations (Wolf et al. 1999a, 2000).

In the context of the geological storage of $\mathrm{CO}_{2}$ a few projects consider the direct injection of flue gases from power plants or other flue gas emitting industries. Part of this research is also to investigate how to use industrial flue gas as an alternative to pure $\mathrm{CO}_{2}$ as an injectant and how it influences the sequestrable amount of $\mathrm{CO}_{2}$ in dry and water saturated coal. The use of flue gas instead of $\mathrm{CO}_{2}$ in the ECBM projects may improve the cost-effectiveness of the ECBM projects considerably due to the elimination of the separation process. Flue gas being primarily $\mathrm{N}_{2}$, the effect of pure $\mathrm{N}_{2}$ as an injectant is also to be investigated. $\mathrm{N}_{2}$ is known to act as a stripper. It is interesting to note that on a field scale, post production $\mathrm{CH}_{4} / \mathrm{N}_{2}$ separation is more expensive than $\mathrm{CO}_{2} / \mathrm{CH}_{4}$ separation.

Coal is characterized by its dual porosity: it contains both primary (micro pores and meso pores) and secondary (macro pores and natural fractures) porosity systems. The primary porosity system contains the vast majority of the gas-in-place, while the secondary porosity system provides the conduit for mass transfer to the wellbore. Primary porosity gas storage is dominated by adsorption. Primary porosity is relatively impermeable due to its small pore size. Mass transfer for each gas molecular species is dominated by diffusion that is driven by the concentration gradient. Flow through the secondary porosity system is dominated by Darcy flow that relates flow rate to permeability and pressure gradient.

The conventional primary CBM recovery process begins with a production well that is often stimulated by hydraulic fracturing to connect the well bore to the coal natural fracture system via an induced fracture (Mazumder et al. 2003). When the pressure in the well is reduced by pumping water by using artificial lift, the pressure in the induced fracture is reduced. This in turn, reduces the pressure in the natural coal fracture system. Initially, when the operation is started, water begins to move in the direction of the pressure gradient. When the pressure of natural fracture system drops below the critical desorption pressure, methane starts to desorb from the primary porosity and is released into the secondary porosity system. As a result, the adsorbed gas concentration in the primary porosity system near the natural fractures is reduced. This reduction creates a concentration gradient that results in mass transfer by diffusion through the micro and meso porosity. Adsorbed gas continues to be released as the pressure is reduced (Reznik et al. 1984).

Enhanced recovery of coalbed methane (ECBM) by injecting a second gas maintains overall reservoir pressure, while lowering the partial pressure of the CBM in the free gas. $\mathrm{CO}_{2}$ which is more strongly adsorbable than methane is injected into the coal natural fracture system during the ECBM recovery process; it is preferentially adsorbed into the primary porosity system (Busch et al. 2004). Upon adsorption the $\mathrm{CO}_{2}$ drives the $\mathrm{CH}_{4}$ from the primary porosity into the secondary porosity system. The secondary porosity pressure is increased due to $\mathrm{CO}_{2}$ injection and the $\mathrm{CH}_{4}$ flows to the injection wells (Shi and Durucan 2003).

The objectives to do the core flood experiments using varied injectants from pure $\mathrm{CO}_{2}$ and $\mathrm{N}_{2}$ to multi-component flue gas are as follows: experiments were conducted to analyze 


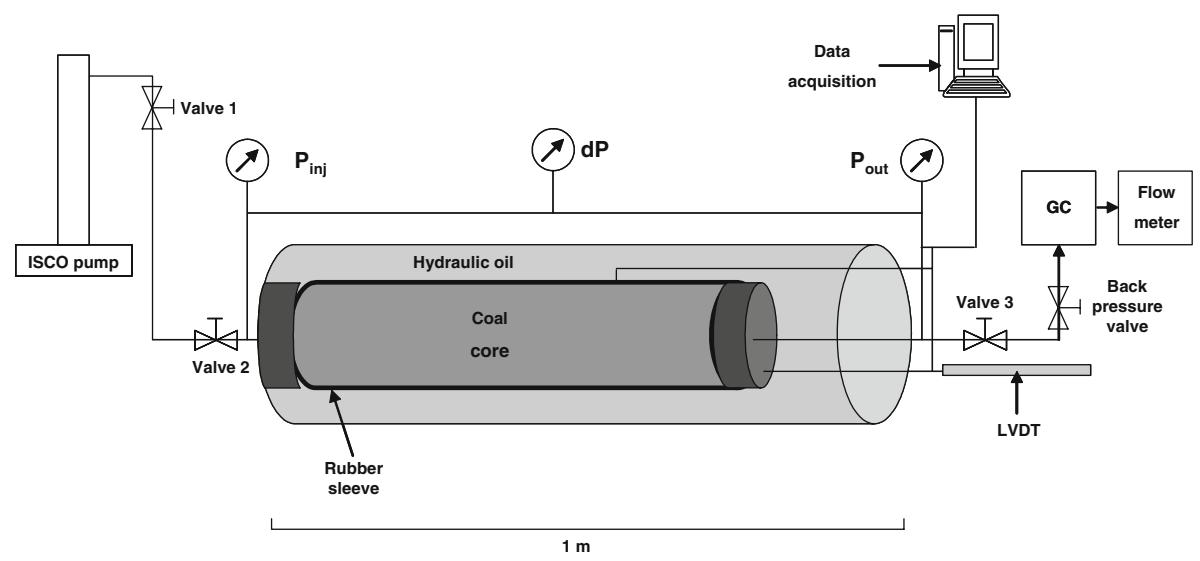

Fig. 1 Schematic of the high pressure flow cell. The volume of the ISCO pump, including the tubing to valve 1 is $283.02 \mathrm{ml}$, of which $266.50 \mathrm{ml}$ can be displaced. The tubing volume between valve 1 and 2 is $44.04 \mathrm{ml}$. The tubing volume between valve 2 and 3 is $74.62 \mathrm{ml}$ (excluding coal volume). The volume of the tubing between valve 3 and the back pressure valve is $46.725 \mathrm{ml}$. All volumes reported are at STP

the influence of injection pressure and injection rate on the methane recovery, evaluate the influence of water on the $\mathrm{CH}_{4}-\mathrm{CO}_{2}$ exchange process in coal by conducting experiments under relatively dry and wet conditions, to differentiate the effects of an alternate injection of a strong $\left(\mathrm{CO}_{2}\right)$ and weak $\left(\mathrm{N}_{2}\right)$ adsorbing gas, to compare the breakthrough time of $\mathrm{CO}_{2}$ from different $\mathrm{CO}_{2}$ core flood experiments and to compare the results of pure $\mathrm{CO}_{2}$ against flue gas flooding experiments.

\section{Equipment Design}

The uniqueness of these experiments, using large cores $(800-1,000 \mathrm{cc})$, makes the design of the setup complex. The reasons to use large core samples are: (i) heterogeneity of the coal matrix is sufficiently guaranteed and (ii) the dual porosity nature of coal is retained. Taking this into consideration a high pressure core flooding setup was constructed. The schematic of the setup is shown in Fig. 1. The pressure cell of $1 \mathrm{~m}$ in length has a maximum confining pressure of $20 \mathrm{MPa}$ and a maximum temperature of $150^{\circ} \mathrm{C}$. The confining pressure was applied on the coal core, inside a rubber sleeve. In order to prevent the gas from diffusing through the rubber sleeve, $0.2 \mathrm{~mm}$ lead foil was wrapped around the coal core. The rubber sleeve is able to transfer the annular pressure onto the sample. In order to simulate down hole conditions the temperature in the pressure cell was maintained at around $45^{\circ} \mathrm{C}$. The pressure cell can handle samples up to a diameter of $120 \mathrm{~mm}$ and a core length of $500 \mathrm{~mm}$. The length of the core varied from sample to sample. In order to avoid mechanical end effects on the core permeability, two sieperm plates are fixed at both ends of the core. These sieperm plates have a porosity of $33 \%$ and a permeability of $10^{-13} \mathrm{~m}^{2}$. The injection and production tubings are attached to the end plates. The end plates also serve for maximal distribution of gas at the injection side.

Following the direction of flow, the high pressure cell consists of the following peripheral devices:

- An ISCO TM plunger pump connected to a bottle of the required gas to be injected. The ISCO plunger pump injects $\mathrm{CO}_{2}, \mathrm{CH}_{4}, \mathrm{~N}_{2}$ and flue gas into the coal core at a constant 
Fig. 2 Measured system pressure during Experiment I (Beringen 770, dry, $\mathrm{CO}_{2}$ injection at $6 \mathrm{ml} / \mathrm{h}$ ). The average effective stress applied was 40 bars

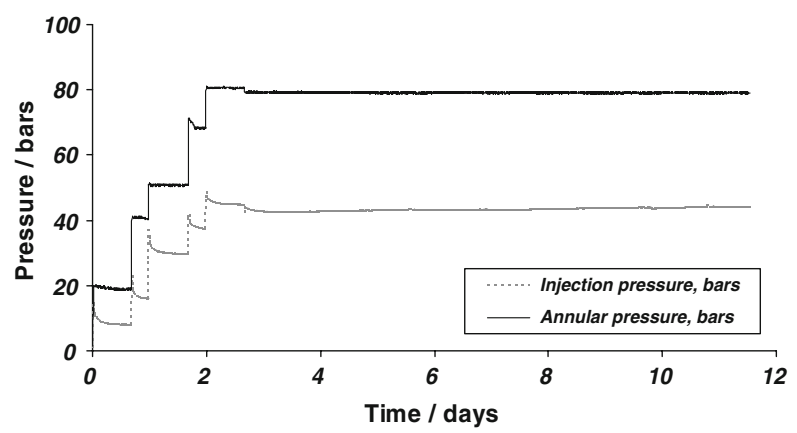

injection rate. The average of the injection and production pressure was taken as the pressure over the core and used for the calculation of the Darcy permeability. At the production end, a back pressure valve controlled the flow out. A constant effective stress was maintained during the experiment.

- A linear variable displacement transformer (LVDT) measured the axial displacement of the core dimension ( $\mu$-strains), throughout the experiment. The cores were drilled parallel to the bedding plane, thus ensuring that the axial strain measured was parallel to bedding.

- Gas analyzer. The gas chromatograph (GC) used for analyzing the product gas was an Agilent $^{\mathrm{TM}} 3000$ micro GC with a Thermal Conductivity Detector (TCD).

- Flow analyzer. At the end of the line an analog flow analyzer, i.e. an Acataris ${ }^{\mathrm{TM}}$ water clock measured the remaining gases leaving the system. This type of analog flow analyzers runs at an accuracy of $0.1 \mathrm{ml} / \mathrm{h}$. The flow rate was camera recorded and afterward used for mass balance calculations and permeability measurements.

- Operational panel, safety device and data acquisition system. The operation panel, the data-acquisition system and safety devices were installed in the control room. During the test, two thermocouples were used to measure temperatures above and below the core inside the pressure cell. In addition, the (differential) pressure, tube/sample expansion and flows were registered every $30 \mathrm{~s}$.

\section{Sample Description}

The unique properties of coal put constraints on preparation and preservation of coal samples. When exposed to air, the effect of drying and weathering results in the alteration of the coal structure and develops new fractures. The permeability and porosity values of such samples may be significantly different from the samples that are well preserved. The cores were drilled from big blocks of coal $\left(>0.25 \mathrm{~m}^{3}\right)$. Coal samples used for these experiments were kept in water to avoid contact with air and drying. Once drilled the cores were put in sealed polyethylene bags and cooled to prevent oxidation or loss of moisture. All the coal cores were drilled parallel to the bedding plane except for Experiment VII, where a vertical drill core was used.

The samples used for these experiments were from the Beringen coal mines (Beringen 770) in Belgium, the Silezia and the Brzeszcze coal mine in Poland and a vertical drill core from the $\mathrm{CO}_{2}$ injection well (seam 401; Well MS3) in Poland. The details of the samples are shown in Table 1. Nine different flooding experiments were conducted on coal cores drilled from the samples mentioned above. The details of the coal cores and their experimental conditions are 
Table 1 Sample properties

\begin{tabular}{|c|c|c|c|c|c|}
\hline Sample & $\operatorname{Rank}\left(\% \mathrm{R}_{\max }\right)$ & $\begin{array}{l}\text { Maceral } \\
\text { composition } \\
(\%)\end{array}$ & & $\begin{array}{l}\text { Specific sur- } \\
\text { face }\left(\mathrm{m}^{2} / \mathrm{g}\right)\end{array}$ & $\begin{array}{l}\text { Micropore } \\
\text { volume } \\
\left(\mathrm{cm}^{3} / \mathrm{g}\right. \\
\text { coal })\end{array}$ \\
\hline \multirow{4}{*}{$\begin{array}{c}\text { Beringen } 770 \\
\text { (Belgium) }\end{array}$} & 0.78 & Vitrinite & 37.8 & 151.53 & 0.055 \\
\hline & & Liptinite & 18.0 & & \\
\hline & & Inertinite & 44.0 & & \\
\hline & & Mineral matter & 0.2 & & \\
\hline \multirow{4}{*}{$\begin{array}{l}\text { Silezia } 315 \text { II } \\
\text { (Poland) }\end{array}$} & 0.68 & Vitrinite & 71.6 & 190.00 & 0.064 \\
\hline & & Liptinite & 6.8 & & \\
\hline & & Inertinite & 15.0 & & \\
\hline & & Mineral matter & 6.8 & & \\
\hline \multirow{4}{*}{$\begin{array}{l}\text { Brzeszcze 501; } \\
\text { LW 405 } \\
\text { (Poland) }\end{array}$} & 0.75 & Vitrinite & 38.8 & 171.00 & 0.058 \\
\hline & & Liptinite & 8.0 & & \\
\hline & & Inertinite & 52.8 & & \\
\hline & & Mineral matter & 0.4 & & \\
\hline \multirow{4}{*}{$\begin{array}{l}\text { Seam } 401 \text { vertical } \\
\text { drill core from } \\
\text { well MS3 } \\
\text { (Poland) }\end{array}$} & 0.85 & Vitrinite & 53.8 & - & - \\
\hline & & Liptinite & 6.3 & & \\
\hline & & Inertinite & 21.2 & & \\
\hline & & Mineral matter & 18.7 & & \\
\hline
\end{tabular}

in Table 2. The Silezia and the Brzeszcze samples were in terms of their maceral composition similar in rank. The Silezia coal was vitrinite rich and the Brzeszcze coal was inertinite rich. The micro-pore volume and specific surface are listed in Table 1.

\section{Preferential Sorption Behaviour}

Volumetric sorption experiments for pure $\mathrm{CH}_{4}$ and $\mathrm{CO}_{2}$ were conducted for all the samples used for the flooding experiments. This data is reported in Appendix D. Only few measurements have been reported for mixtures of two or more gas components under the conditions of competitive sorption. Very few data showed preferential adsorption of $\mathrm{CO}_{2}$ and preferential desorption of $\mathrm{CH}_{4}$, as commonly expected. Busch et al. (2006) reported distinct variations in the competitive adsorption and desorption behaviour of the different dry and moist samples, ranging from preferential adsorption of $\mathrm{CH}_{4}$ in the low pressure range to preferential desorption of $\mathrm{CO}_{2}$ over the entire pressure range. The preferential sorption behaviour of the Silezia and Brzeszcze samples has been reported by Busch et al. (2006).

Differences in the sorption behaviour were observed between the coals as well as between measurements performed on dry and moist samples. The most conspicuous difference in the preferential adsorption with respect to moisture content was found for the coal sample from the Silesia mine: the moist Silesia 315 sample exhibits significant preferential adsorption of $\mathrm{CH}_{4}$ up to about $6 \mathrm{MPa}$ and then switches to preferential $\mathrm{CO}_{2}$ adsorption (Busch et al. 2006). In contrast, the dry sample shows no fractionation for the first measured data point at about $1 \mathrm{MPa}$, followed by preferential adsorption of $\mathrm{CO}_{2}$ with increasing pressure (Busch et al. 


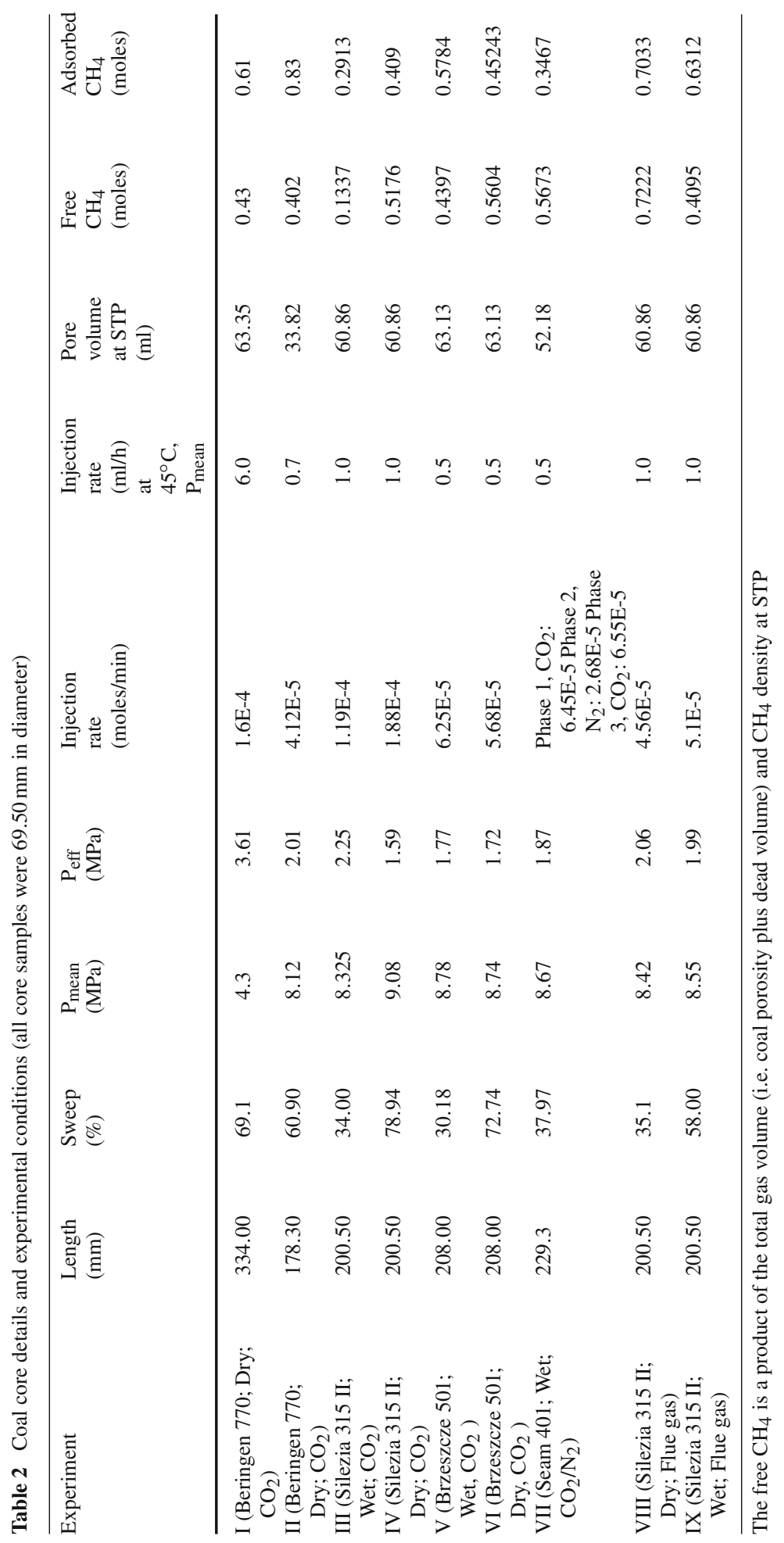


2006). This observation could be due to competition of water and $\mathrm{CO}_{2}$ for specific sorption sites in the moist sample or due wettability reversal (water wet to $\mathrm{CO}_{2}$ wet). The desorption trends of both experiments are similar and indicate only slight tendency for preferential desorption of $\mathrm{CO}_{2}$ in the low-pressure range. For the Brzeszcze coal sample, preferential desorption of $\mathrm{CO}_{2}$ is evident over the complete pressure range for the dry, and even more clearly so for the moist sample. For the adsorption trend there is a clear preferential adsorption of $\mathrm{CO}_{2}$ over the entire pressure range for the dry sample. The moist Brzeszcze adsorbs $\mathrm{CH}_{4}$ preferentially up to about $5.5 \mathrm{MPa}$ with an opposite trend for the high pressure range (Busch et al. 2006), the dry sample shows preferential adsorption of $\mathrm{CO}_{2}$ over the entire pressure range. When comparing the results for the samples it is difficult to detect any distinct relationship between the preferential sorption behaviour and maceral composition or rank. Although all the samples are high volatile bituminous coals, they show distinct differences in their sorption behaviour, which, therefore, cannot be attributed to rank. However, there appears to be regularity in the selective sorption behaviour with respect to moisture content. Although the preferential adsorption trend is not uniform throughout the sample set, moist coals exhibit a reduced tendency towards preferential $\mathrm{CO}_{2}$ adsorption as compared to dry coals (Busch et al. 2006). The maceral composition might be an influencing factor, because the sample with the highest inertinite content (Brzeszcze) shows the highest degree of preferential $\mathrm{CO}_{2}$ desorption within the sample set.

\section{Experimental Procedure and Data Interpretation}

The experiments start with a complex procedure of mounting the lead foil wrapped coal core in a rubber sleeve and building it leak free in the high-pressure cell. A detailed procedure for volume measurement was then followed. The volume measurements were conducted with and without the sample built in the pressure cell. The details of the void volume measurements are discussed in Appendix A. The tubing volume in the whole setup is quite considerable. The effect of this dead volume is seen in the results and has been discussed later in this section. All mass balance calculations for $\mathrm{CH}_{4}$ and $\mathrm{CO}_{2}$ do take care of the free and the adsorbed volumes separately.

At the end of the volume measurement the sample cell was, for at least a week connected to a vacuum pump, to eliminate any form of residual gas or free moisture. During this process temperature was kept constant. Experiment IV (Silezia $315 \mathrm{II}$; Dry; $\mathrm{CO}_{2}$ ) is used as an example to describe the test procedure. The flooding test, which lasted a total of 45 days, consisted of three consecutive stages (Fig. 14): (i) $\mathrm{CH}_{4}$ loading, (ii) $\mathrm{CO}_{2}$ loading, and (iii) continued $\mathrm{CO}_{2}$ injection with production under a constant pressure. In a typical wet experiment, the $\mathrm{CO}_{2}$ loading stage is replaced by a water loading phase (Fig. 34). In the first stage (7 days), 20.761 of $\mathrm{CH}_{4}$ was injected into the system in increasing pressure cycles, till the required saturation was reached. The system pore pressure rose to $6 \mathrm{MPa}$ during two days of injection. After each injection cycle the methane was allowed to sorb onto the coal matrix until equilibrium was reached. In order to meet sub-surface conditions, the difference between the annular pressure and the pore pressure was usually kept at ratios of 2:1 to 5:3. The volume of injected methane was measured with a mass flow meter. The free methane is the product of the total gas volume (i.e. coal porosity plus dead volume) multiplied by the methane density at a particular P,T condition. The sorbed methane is the difference between the total amounts of methane injected in the system minus the free methane. The typical pressure profile during methane loading is shown in Figs. 14 and 34. During the second stage (21 days), the system was further pressurized to $9.0 \mathrm{MPa}$, with the injection of 32.21 of $\mathrm{CO}_{2}$ 


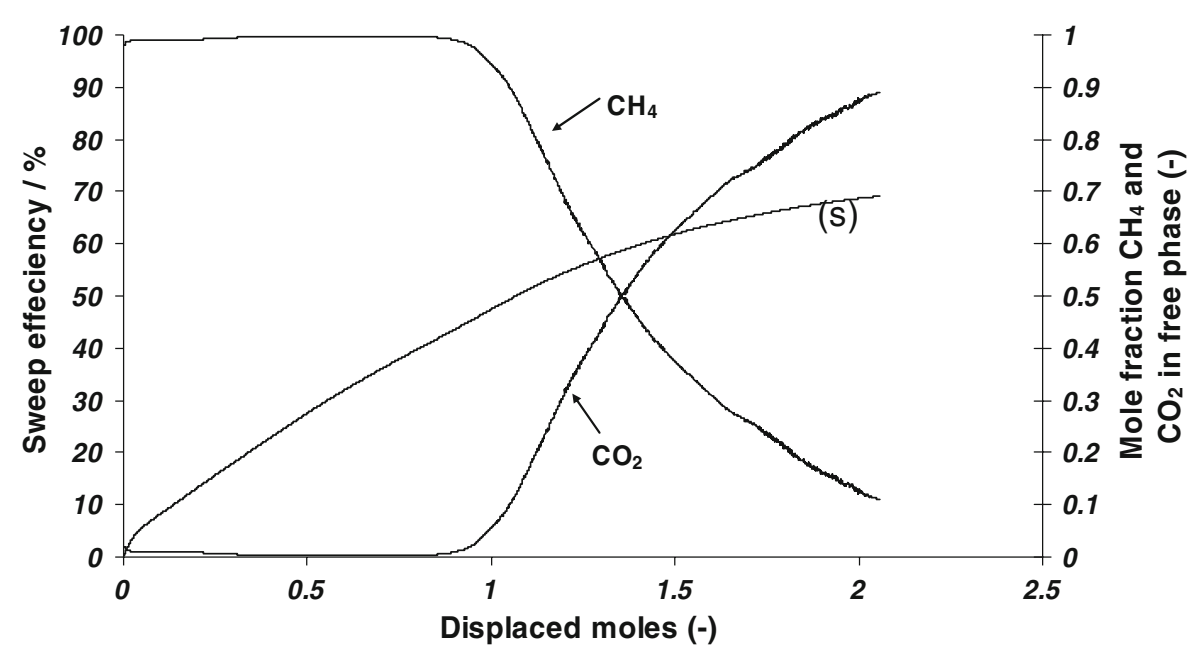

Fig. 3 Sweep efficiency $(s)$ and molar concentrations of the produced gas against displaced moles from Experiment I (Beringen 770, dry, $\mathrm{CO}_{2}$ injection at $6 \mathrm{ml} / \mathrm{h}$ ). The migration data have been plotted against displaced volume to make time dimensionless

in both gas phase and super-critical state. $\mathrm{CO}_{2}$ was injected at a rate of approximately 1.89 1/day. In the following injection cycle the pump was filled with $\mathrm{CO}_{2}$ or flue gas and injection was started. In the final stage (17 days) 71.31 of super-critical $\mathrm{CO}_{2}$ was injected at a rate of 4.191/day. It brings the total amount of injected $\mathrm{CO}_{2}$ to 103.51 . All volume measurements referred to are under the specific experimental conditions. Keeping a constant effective stress over the whole core, with the help of a back pressure valve, the system produced alongside injection. Throughout the final stage the system pressure was maintained at about $9 \mathrm{MPa}$. The injection rate, under experimental $\mathrm{P}$, $\mathrm{T}$ conditions is low when compared to the total volume. The differential pressure over the sample is, therefore, negligible. Measurements of the differential pressure over the sample are less than $500 \mathrm{mbar}$. The reason to use these low injection rate was to simulate the gas exchange away from the well or simulate slow exchange processes. Furthermore, in these experiments an approach to attain local steady state conditions have been made.

The gas analyzer determined the relative amount of $\mathrm{CH}_{4}, \mathrm{CO}_{2}$ and $\mathrm{N}_{2}$ alongside other gases in the product (Fig. 3). The GC measurements were assumed to be representative of the change in molar concentrations of each component in the free phase. For the $\mathrm{CO}_{2}$ flooding experiments, the experiment was stopped when the relative amount of carbon dioxide in the product gas reached $98 \%$. The moisture, if present was separated using a silica gel bottle connected to a balance. Hence, for wet experiments the amount of water flowing out was measured. During the tests the recorded data serve as an iterative feedback to control injection volumes for mass balance calculations afterwards.

\section{Results and Discussion}

\section{1 $\mathrm{CO}_{2}$ Core Flood Experiments}

The seven different $\mathrm{CO}_{2}$ core flood experiments (Table 2) range from sub-critical to supercritical $\mathrm{CO}_{2}$ conditions. In order to compare the effect of varying injection rate and injection 
Table 3 Sweep efficiency, displaced moles and time of Experiments I and II

\begin{tabular}{|c|c|c|c|c|c|c|}
\hline \multirow{2}{*}{$\begin{array}{l}\mathrm{CO}_{2} \\
\text { flooding } \\
\text { (Beringen } \\
770 \text { ) }\end{array}$} & \multicolumn{2}{|l|}{$\mathrm{CO}_{2}=1 \%$} & \multicolumn{2}{|l|}{$\mathrm{CO}_{2}=50 \%$} & \multicolumn{2}{|l|}{$\mathrm{CO}_{2}=90 \%$} \\
\hline & Dry $(6 \mathrm{ml} / \mathrm{h})$ & Dry $(0.7 \mathrm{ml} / \mathrm{h})$ & Dry $(6 \mathrm{ml} / \mathrm{h})$ & $\operatorname{Dry}(0.7 \mathrm{ml} / \mathrm{h})$ & Dry $(6 \mathrm{ml} / \mathrm{h})$ & Dry $(0.7 \mathrm{ml} / \mathrm{h})$ \\
\hline $\begin{array}{l}\text { Sweep } \\
\text { efficiency } \\
(\%)\end{array}$ & 43.6 & 22.9 & 58.8 & 46.7 & 69.1 & 58.7 \\
\hline $\begin{array}{l}\text { Displaced } \\
\text { moles } \\
\text { (mole/mole) }\end{array}$ & 0.91 & 1.77 & 1.36 & 5.1 & 2.06 & 10.63 \\
\hline $\begin{array}{l}\text { Time after } \\
\text { production (s) }\end{array}$ & $3.36 \times 10^{5}$ & $6.6 \times 10^{5}$ & $5.0 \times 10^{5}$ & $19.0 \times 10^{5}$ & $7.7 \times 10^{5}$ & $39.6 \times 10^{5}$ \\
\hline
\end{tabular}

Fig. 4 Cumulative production of all gases, and injection of $\mathrm{CO}_{2}$ from Experiment I (Beringen 770 , dry, $\mathrm{CO}_{2}$ injection at $6.0 \mathrm{ml} / \mathrm{h}$ )

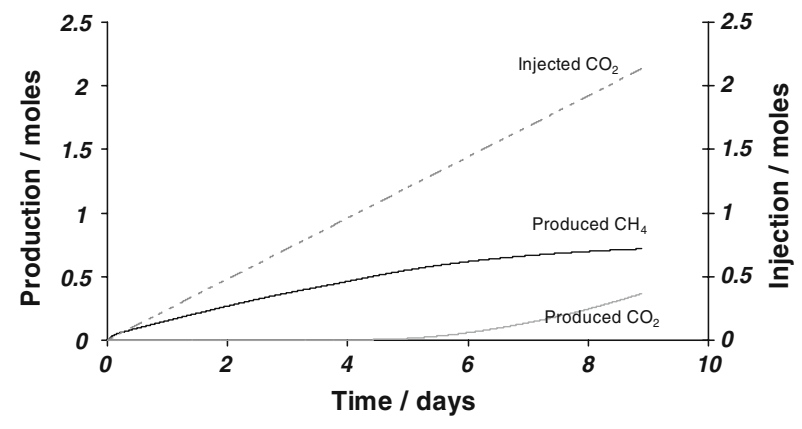

Fig. 5 Injection and production flow rate of gases for Experiment I at STP. The breakthrough of $\mathrm{CO}_{2}$ took place 4 days after the initiation of simultaneous injection and production

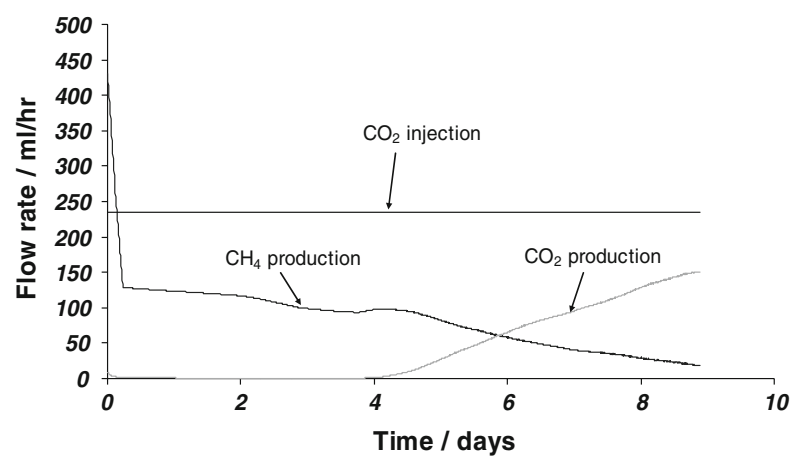

pressure on the methane recovery, the results of Experiments I and II have been listed in Table 3. The experimental conditions prior to the start of $\mathrm{CO}_{2}$ injection are in Table 2. Figs. 3 and 7 show migration history of $\mathrm{CH}_{4}$ and $\mathrm{CO}_{2}$ Both the experiments were conducted at a temperature of $45^{\circ} \mathrm{C}$. While the injection rate for Experiment I was $6 \mathrm{ml} / \mathrm{h}$, that of Experiment II was set as low as $0.7 \mathrm{ml} / \mathrm{h}$. Pressure and temperature conditions were sub-critical for Experiment I, but were super-critical for Experiment II. As can be seen from the migration data (Figs. 3 and 7) the injection pressure does not have a big influence on the methane recovery. Diffusion is much faster under sub-critical conditions as compared to super-critical conditions. $\mathrm{CO}_{2}$ is five times more denser than $\mathrm{CH}_{4}$ under super-critical conditions. 
Fig. 6 Measured system pressure during Experiment II (Beringen 770, dry, $\mathrm{CO}_{2}$ injection at $0.7 \mathrm{ml} / \mathrm{h}$ ). The average effective stress applied was 20 bar. The initial phase of $\mathrm{CH}_{4}$ loading is followed by the stable injection pressures during which simultaneous injection and production was carried out

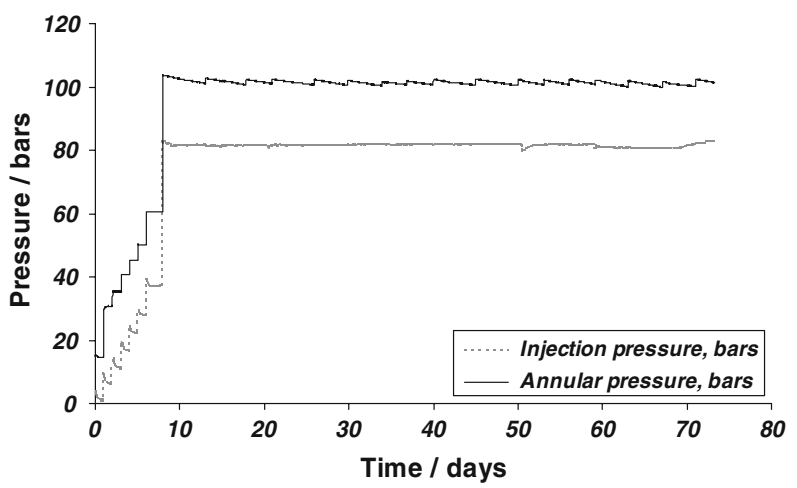

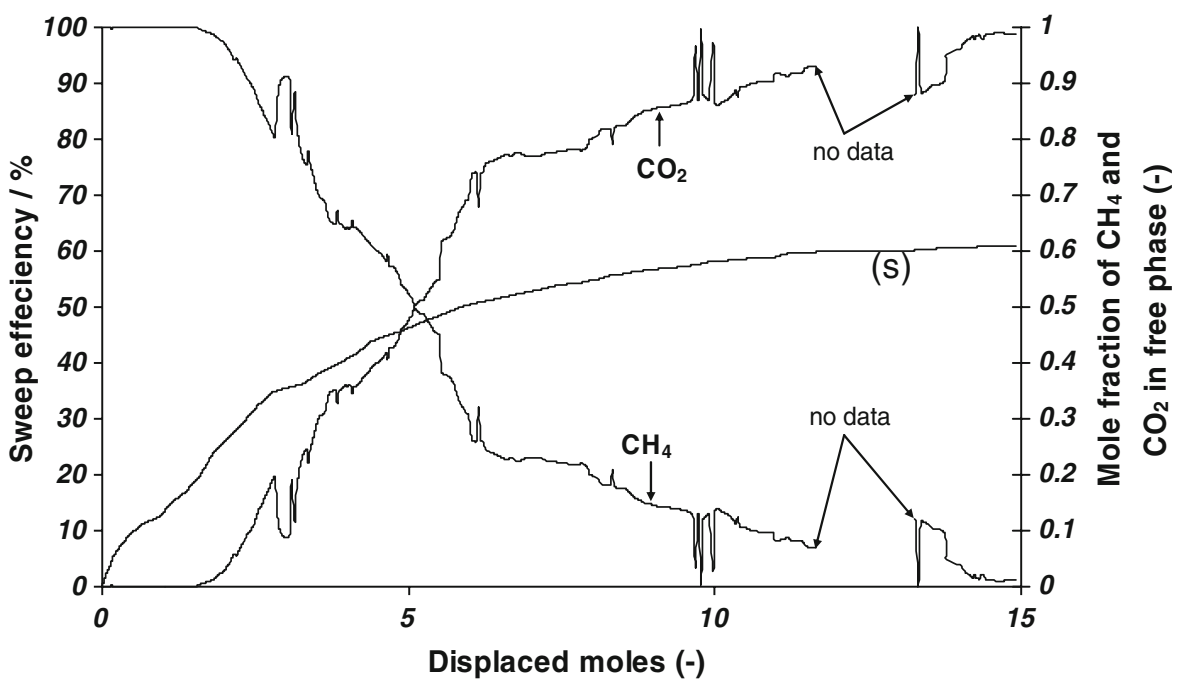

Fig. 7 Sweep efficiency $(s)$ and molar concentrations of the produced gas against displaced moles from Experiment II (Beringen 770, dry, $\mathrm{CO}_{2}$ injection at $0.7 \mathrm{ml} / \mathrm{h}$ ). The $\mathrm{GC}$ response is dependent on the opening and the closure of the back pressure valve. This brings about fluctuations on the migration data. Some of the sharp events on the plot shown above are due to events like pump filling, heating failure, pressure fluctuations etc.

Sweep efficiency and displaced moles are defined as follows (Bertheux 2000):

$$
\begin{aligned}
\text { sweep efficiency }(\%) & =\frac{\text { moles of } \mathrm{CH}_{4} \text { produced }}{\text { moles of } \mathrm{CH}_{4} \text { initially in place }} \times 100 ; \\
\text { displaced moles } & =\frac{\text { moles of injected displacing gas }}{\text { moles of } \mathrm{CH}_{4} \text { initially in place }} .
\end{aligned}
$$

\subsubsection{Binary Displacement for Beringen Coal}

Figures 2-9 shows the pressure history, molar concentration change, cumulative production and injection of all gases and the injection/production flow rate at STP for the two experiments 


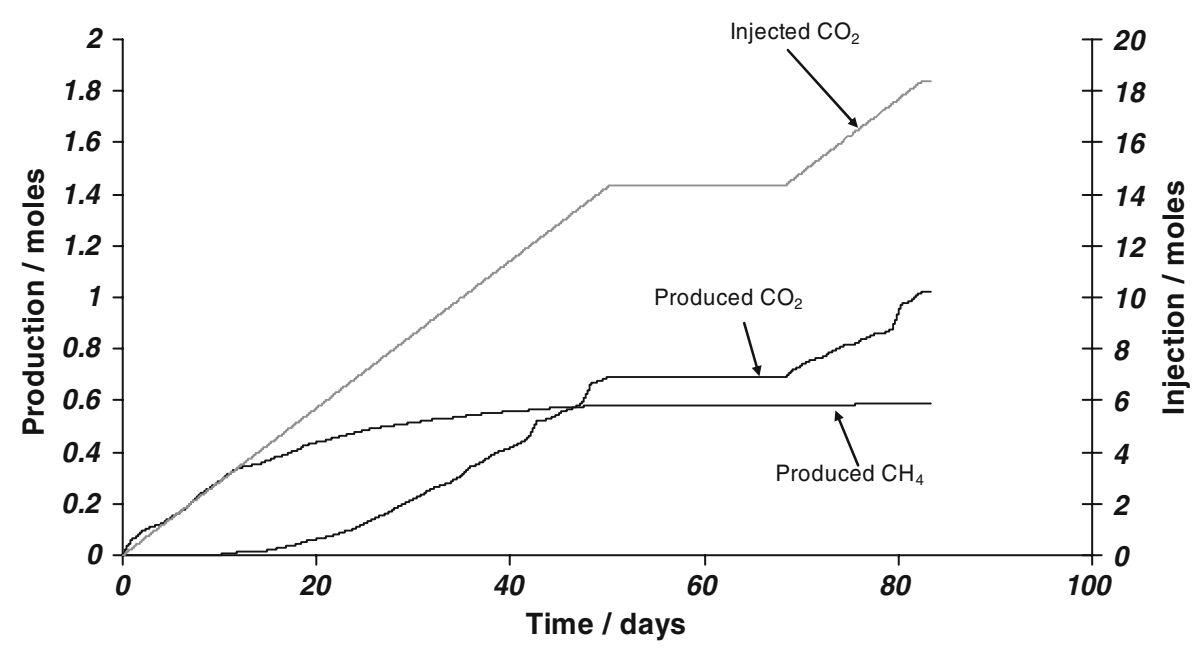

Fig. 8 Cumulative production of all gases, and injection of $\mathrm{CO}_{2}$ from Experiment II (Beringen 770, dry, $\mathrm{CO}_{2}$ injection at $0.7 \mathrm{ml} / \mathrm{h}$ ). Considerable difference between the injected and produced volumes of $\mathrm{CO}_{2}$ can be observed

Fig. 9 Injection and production flow rate of gases for Experiment II at STP

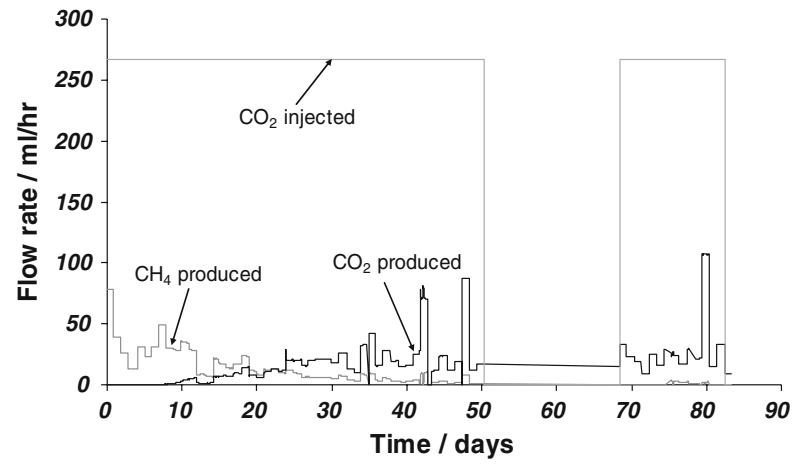

conducted on the Beringen coal. As can be seen from Figs. 2 and 6, Experiment I was conducted at almost half the injection pressure as compared to Experiment II. On the other hand, the effective stress for Experiment I was almost twice as high as that of Experiment II. The molar rate of injection for Experiment $\mathrm{I}$ is almost four times higher than that of Experiment II (Table 2). The coal core used in Experiment I is twice as long as that of Experiment II (Table 2). As can be seen from Table 3, the breakthrough time for Experiment $\mathrm{I}$ is almost two times faster than Experiment II. Also at breakthrough $\left(1 \% \mathrm{CO}_{2}\right)$, almost all the free methane in the system has been produced, whereas only half the free volume of methane was produced for the second case. From the displaced moles data, it is evident that in terms of simple methane recovery, at $90 \%$ of product $\mathrm{CO}_{2}$ concentration, Experiment I might look more efficient as it takes almost five times less time to remove almost equal concentration of $\mathrm{CH}_{4}$ from the system. It can be seen that for better exchange and storage of $\mathrm{CO}_{2}$, the residence time for $\mathrm{CO}_{2}$ in the coal has to be longer (Wolf et al. 1999b). Diffusion is more pronounced in Experiment II than in Experiment I where the injected $\mathrm{CO}_{2}$ moves fast through the core. 
Fig. 10 Measured system pressure during Experiment III (Silezia 315 II, wet, $\mathrm{CO}_{2}$ injection at $1.0 \mathrm{ml} / \mathrm{h}$ ). The average effective stress applied was 20 bars. Only the pressure history during the production phase is shown here

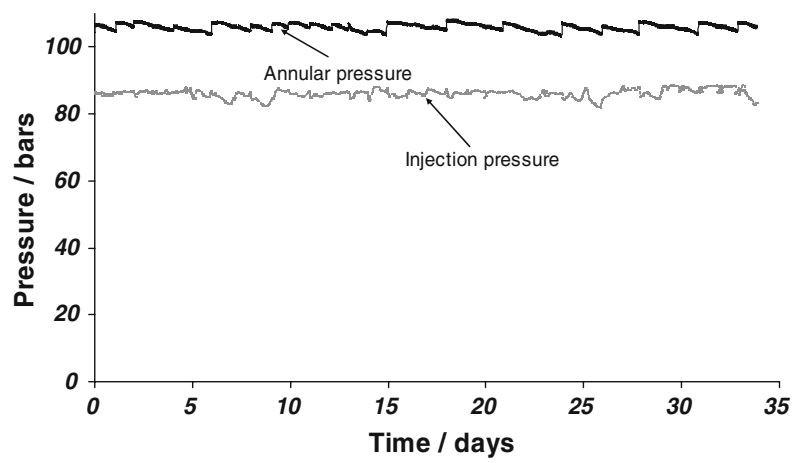

\subsubsection{Binary Displacement for Silezia Coal}

Figures 10-17 shows the pressure history, molar concentration change, cumulative production and injection of all gases and the injection/production flow rate at STP for the two experiments conducted on the Silezia coal. The coal sample of Experiment III and IV have a higher vitrinite content $(71.6 \%)$ than the inertinite content (15\%). Experiments III and IV were conducted to compare the influence of water on the $\mathrm{CO}_{2}-\mathrm{CH}_{4}$ exchange process in the coal. Considerable influence of water in methane recovery have been predicted by Mazumder et al. (2003) by means of numerical simulation. The experimental conditions for these experiments have been shown in Table 2. Both the experiments were conducted on the same coal sample. Experiment II was conducted on a wet coal core with excess water in the fracture system of the coal. No free water was present in the relatively dry Experiment IV. The comparative results of the experiments have been summarized in Tables 4 and 5. The duration of the wet experiment was much longer than the dry one. As can be seen from Table 2 , only $34 \%$ of the $\mathrm{CH}_{4}$ in place was produced at the end of the wet experiment, whereas almost $79 \%$ of the $\mathrm{CH}_{4}$ in place was produced from the dry experiment. An estimate from the above figures show that, apart from the free methane that was produced, only $3 \%$ of the adsorbed methane was produced from the wet experiment as compared to $50 \%$ from the dry experiment. Table 5 shows that there is no considerable difference in the breakthrough time for both experiments. For the wet experiment the slightly faster breakthrough is due to the solution of $\mathrm{CO}_{2}$ in the produced water from the fracture spacings. The wet displacement experiment was conducted for a period of 57 days compared to the dry displacement experiment, which was conducted for 38 days. There is no possible explanation for the excess $\mathrm{CO}_{2}$ being sorbed in the wet experiment. Solution effect of $\mathrm{CO}_{2}$ in water might be a possible effect. Repeat experiments needs to be conducted to understand the effect. From the sweep efficiencies at different times from Table 5, the methane recovery for the relatively dry experiments are much higher as compared to the wet experiment. The $\mathrm{CO}_{2}$ storage capacity remains constant. This also indicate that $\mathrm{CO}_{2}$ occupies different sorption sites than $\mathrm{CH}_{4}$ (Clarkson and Bustin 1999). The presence of $\mathrm{CO}_{2}$ does not affect the sorption capacity of $\mathrm{CH}_{4}$. The $\mathrm{CO}_{2}$ and $\mathrm{CH}_{4}$ migration data for both the experiments are presented in Figs. 11 and 15. Figure 12 is a plot of the injection and the production details of Experiment III, which shows two distinct phases of the water production. One, with most of the free water in the fractures, produced in a short span of time, and second from the macro pores, produced much slower. 


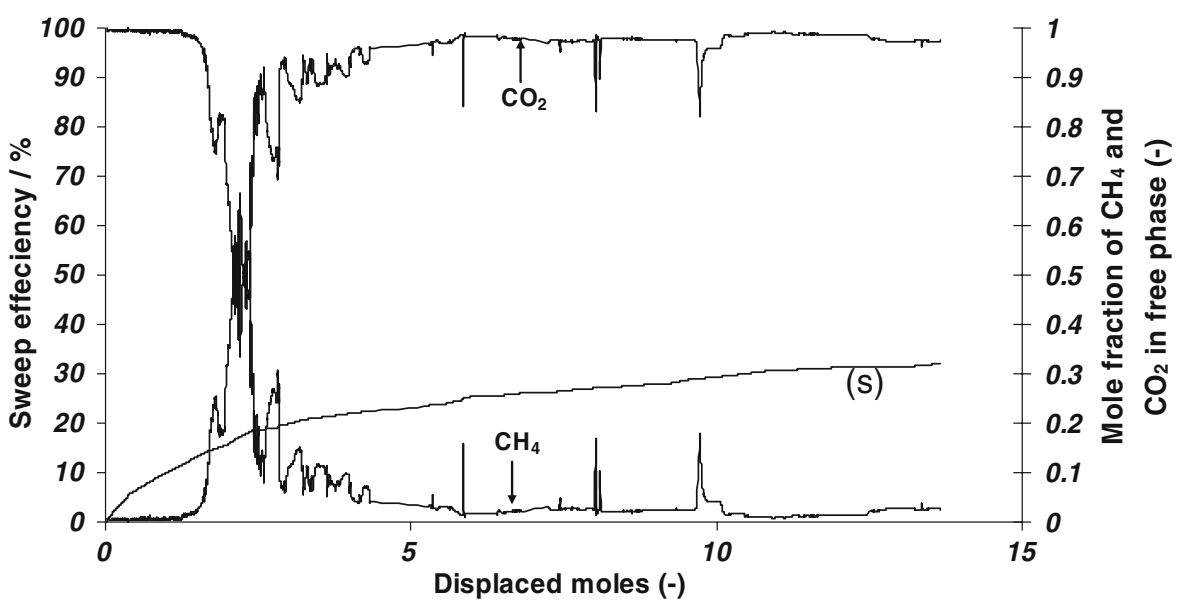

Fig. 11 Sweep efficiency and molar concentration of the produced gas against displaced moles from Experiment III (Silezia $315 \mathrm{II}$, wet, $\mathrm{CO}_{2}$ injection at $1.0 \mathrm{ml} / \mathrm{h}$ )

Fig. 12 Cumulative production of all gases, water and injection of $\mathrm{CO}_{2}$ from Experiment III (Silezia 315 II, wet, CO2 injection at $1.0 \mathrm{ml} / \mathrm{h}$ )
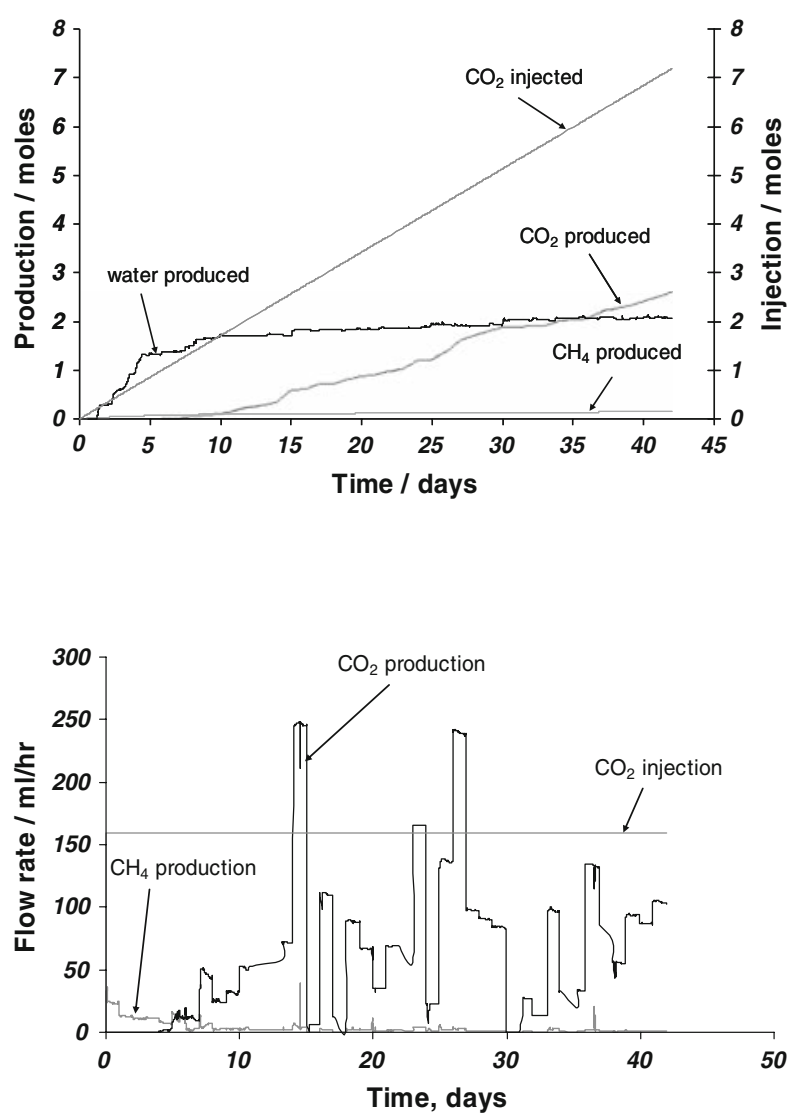

Fig. 13 Injection and production flow rate of gases for Experiment III at STP 


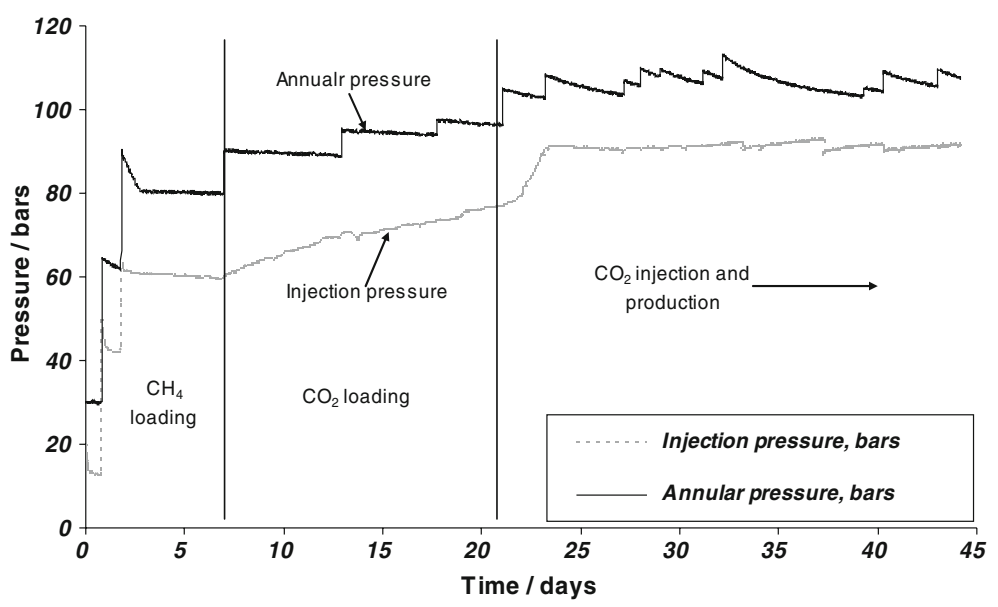

Fig. 14 Measured system pressure and cumulative $\mathrm{CO}_{2}$ injection during the test. The purpose of the $\mathrm{CO}_{2}$ loading phase was to bring up the injection pressure to super-critical conditions and to provide more residence time for $\mathrm{CO}_{2}$ in the pressure cell

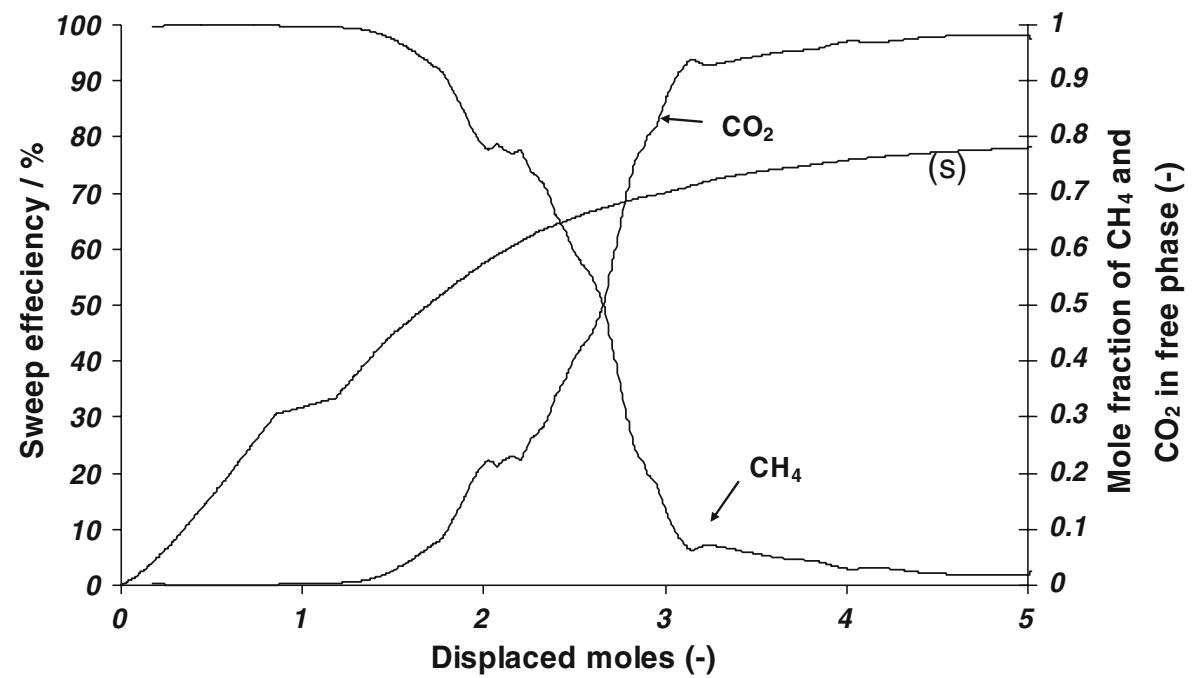

Fig. 15 Sweep efficiency and molar concentrations of the produced gas against displaced moles from Experiment IV (Silezia $315 \mathrm{II}$, dry, $\mathrm{CO}_{2}$ injection at $1.0 \mathrm{ml} / \mathrm{h}$ )

\subsubsection{Binary Displacement for Brzeszcze Coal}

Figures 18-25 shows the pressure history, molar concentration change, cumulative production and injection of all gases and the injection/production flow rate at STP for the two experiments conducted on the Brzeszcze coal. Experiments V and VI were conducted on a coal sample which had a higher inertinite content $(52.8 \%)$ than vitrinite content $(38.8 \%)$. These experiments were conducted to see the effect of water on methane recovery. The results of experiments V and VI are listed in Tables 6 and 7. The migration history of these experiments are in Figs. 19 and 23. The injection and production data for Experiment $\mathrm{V}$ are 
Fig. 16 Cumulative production of all gases, and injection of $\mathrm{CO}_{2}$ from Experiment IV (Silezia 315 II, dry, CO2 injection at $1.0 \mathrm{ml} / \mathrm{h}$ )
Fig. 17 Injection and production flow rate of gases for Experiment IV at STP

Table 4 The total, free, adsorbed and produced amount of carbon dioxide in the dry and wet Silesia 315 II flooding experiment
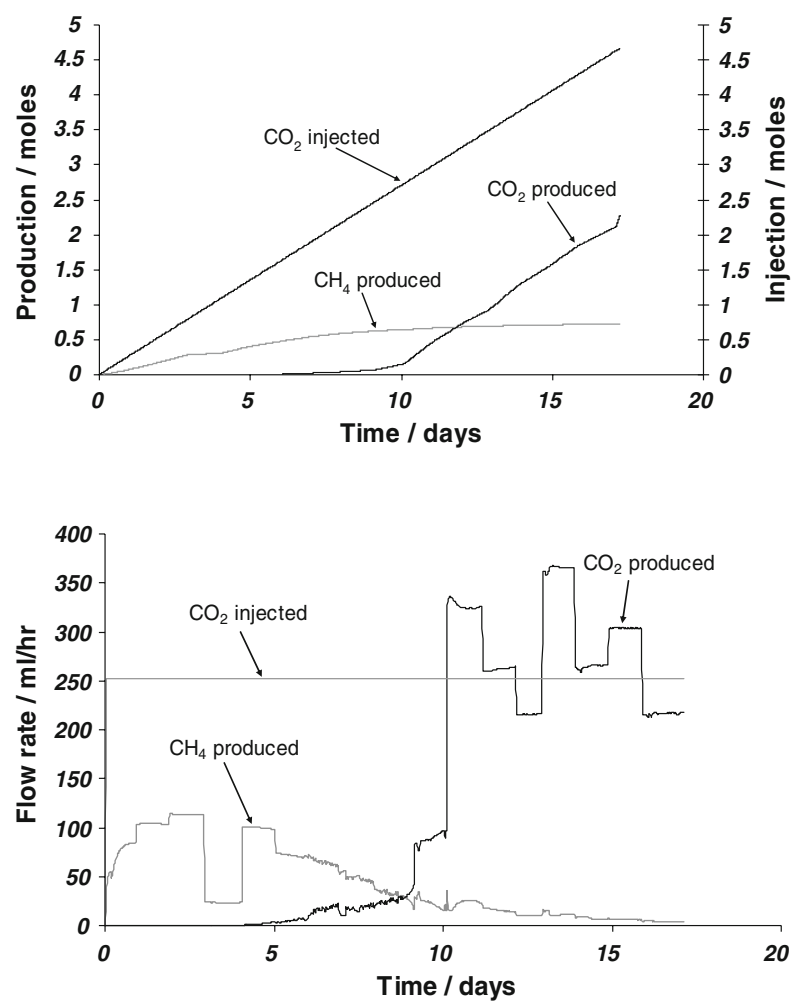

\begin{tabular}{llc}
\hline $\mathrm{CO}_{2}$ flooding (Silesia & Dry & Wet \\
\hline $315 \mathrm{II})$ & 4.665 & 7.18 \\
\hline $\begin{array}{l}\text { Total amount of } \mathrm{CO}_{2} \\
\text { injected (moles) }\end{array}$ & $1.604(\max )$ & 3.83 \\
$\begin{array}{c}\text { Amount of adsorbed } \\
\mathrm{CO}_{2} \text { (moles) }\end{array}$ & 0.7823 & 0.7394 \\
$\begin{array}{c}\text { Amount of free } \mathrm{CO}_{2} \\
(\text { moles) }\end{array}$ & 2.279 & 2.62 \\
$\begin{array}{c}\text { Total amount of } \mathrm{CO}_{2} \\
\text { produced (moles) }\end{array}$ & & \\
\hline
\end{tabular}

listed in Fig. 20. These two experiments showed different results as compared to Experiments III and IV. Significant differences in the methane recovery was noted between the wet (Experiment V) and dry (Experiment VI) experiments. It could not be explained if the early breakthrough was caused by inherent characteristic for an inertinite rich coal or due to an easy pathway through which the $\mathrm{CO}_{2}$ moved directly to the production side (preferential flow). Field experiments in Poland also suggest very early breakthrough of $\mathrm{CO}_{2}$ from these coals in the production well. Note that the injection rate for Experiment V and VI is half of that for Experiments III and IV. It is also true that the maceral composition of these coals, have big influence in the $\mathrm{CO}_{2}-\mathrm{CH}_{4}$ exchange process. 
Table 5 Sweep efficiency, displaced moles and time of Experiment III and IV

\begin{tabular}{|c|c|c|c|c|c|c|}
\hline \multirow{2}{*}{$\begin{array}{l}\mathrm{CO}_{2} \\
\text { flooding } \\
\text { (Silesia } \\
315 \mathrm{II}) \\
\end{array}$} & \multicolumn{2}{|l|}{$\mathrm{CO}_{2}=1 \%$} & \multicolumn{2}{|l|}{$\mathrm{CO}_{2}=50 \%$} & \multicolumn{2}{|l|}{$\mathrm{CO}_{2}=90 \%$} \\
\hline & Dry & Wet & Dry & Wet & Dry & Wet \\
\hline $\begin{array}{l}\text { Sweep } \\
\text { efficiency } \\
(\%)\end{array}$ & 37.2 & 11.6 & 66.25 & 16.5 & 69.8 & 19.5 \\
\hline $\begin{array}{l}\text { Displaced } \\
\text { moles } \\
\text { (mole/mole) }\end{array}$ & 1.28 & 1.26 & 2.56 & 2.09 & 2.96 & 2.86 \\
\hline $\begin{array}{l}\text { Time after } \\
\text { production (s) }\end{array}$ & $3.8 \times 10^{5}$ & $2.7 \times 10^{5}$ & $7.6 \times 10^{5}$ & $4.5 \times 10^{5}$ & $8.8 \times 10^{5}$ & $6.1 \times 10^{5}$ \\
\hline
\end{tabular}

Fig. 18 Measured system pressure during Experiment $\mathrm{V}$ (Brzeszcze, wet, $\mathrm{CO}_{2}$ injection at $0.5 \mathrm{ml} / \mathrm{h}$ ). The average effective stress applied was 20 bars
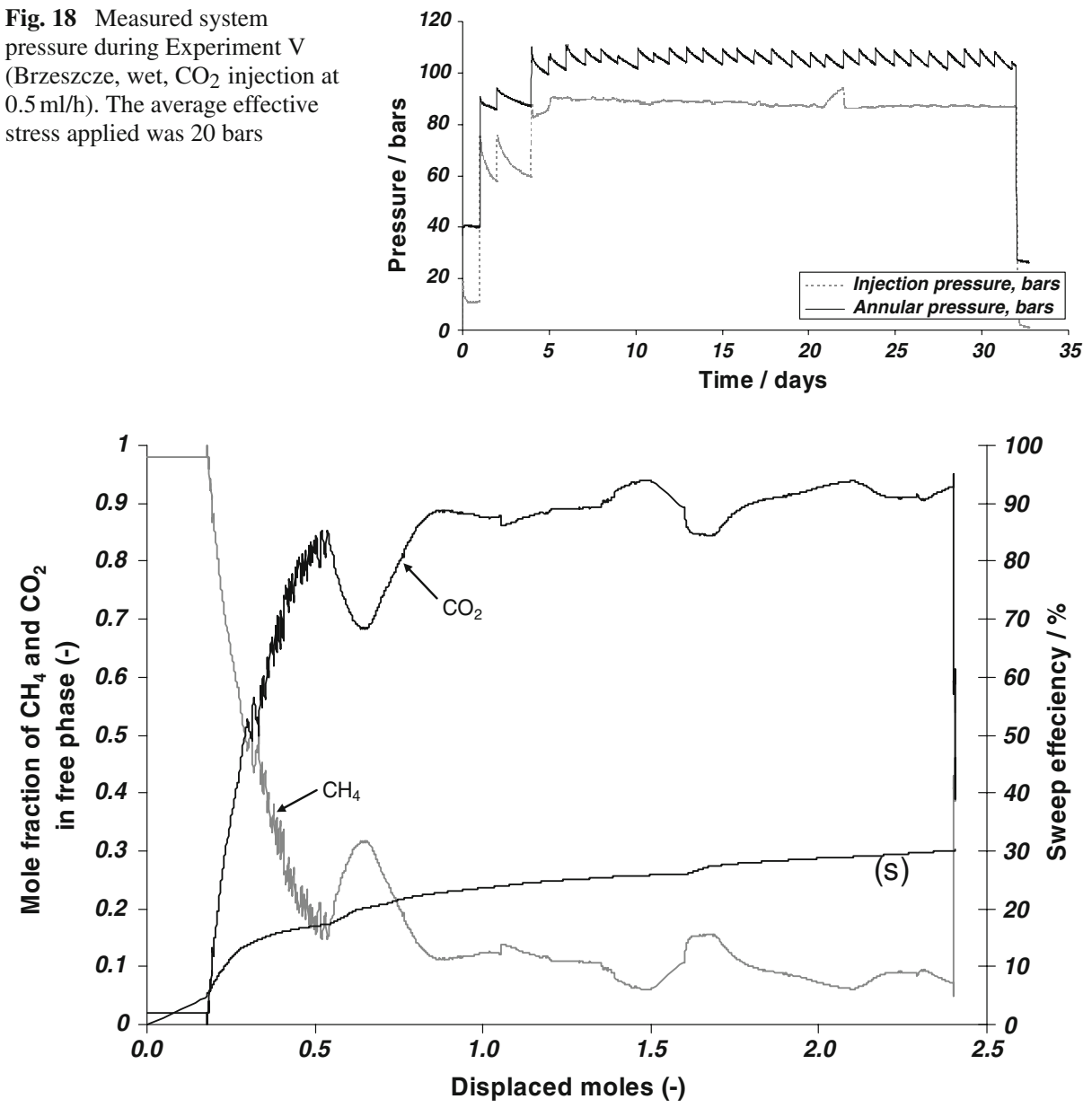

Fig. 19 Sweep efficiency and molar concentrations of the produced gas against displaced moles from Experiment V (Brzeszcze, wet, $\mathrm{CO}_{2}$ injection at $0.5 \mathrm{ml} / \mathrm{h}$ ) 
Fig. 20 Cumulative production of all gases, water and injection of $\mathrm{CO}_{2}$ from Experiment $\mathrm{V}$ (Brzeszcze, wet, $\mathrm{CO} 2$ injection at $0.5 \mathrm{ml} / \mathrm{h}$ )

Fig. 21 Injection and production flow rate of gases for Experiment $\mathrm{V}$ at STP

Fig. 22 Measured system pressure during Experiment VI (Brzeszcze, dry, $\mathrm{CO}_{2}$ injection at $0.5 \mathrm{ml} / \mathrm{h}$ ). The average effective stress applied was 20 bars
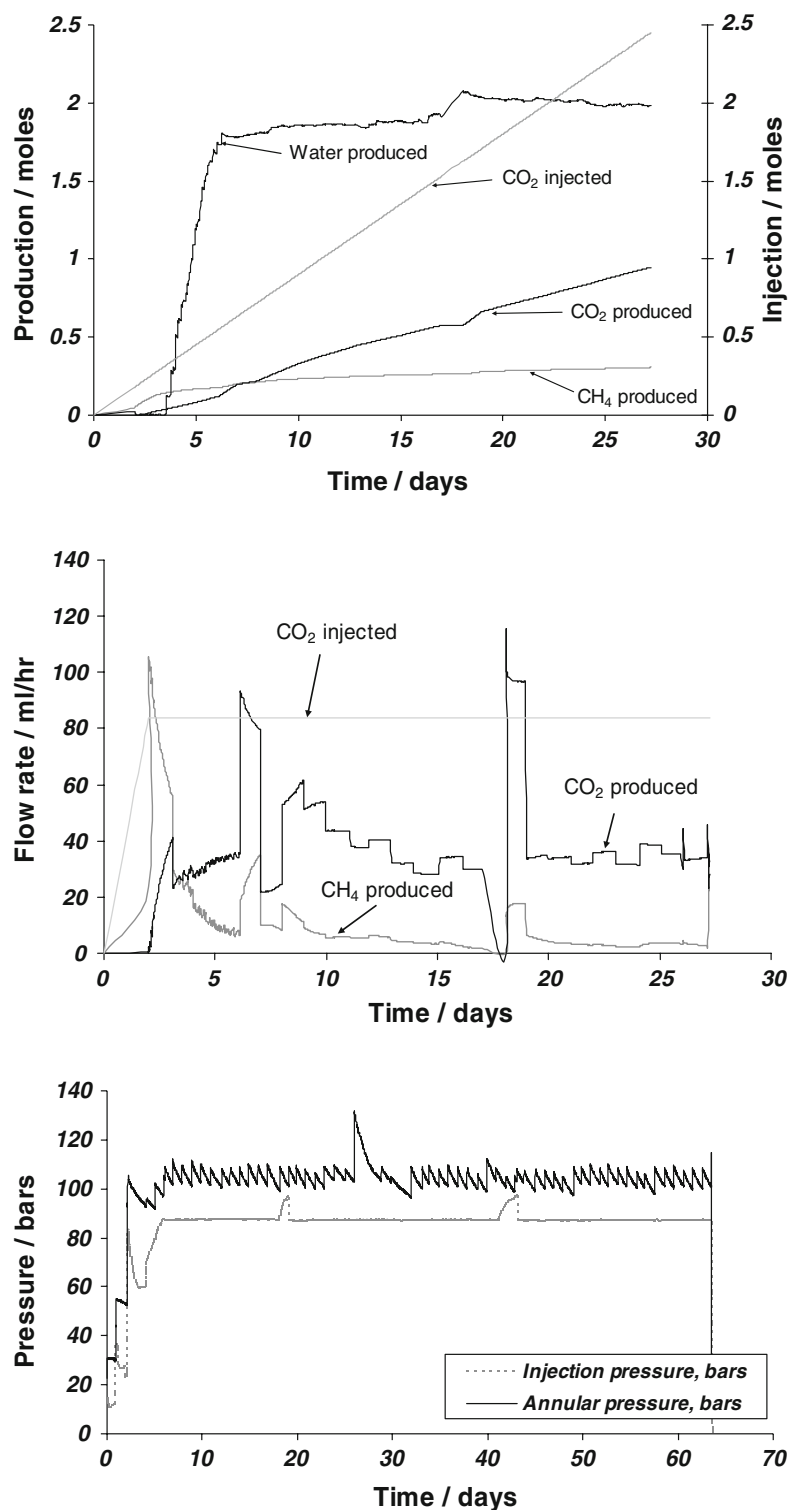

\subsubsection{Ternary Displacement for Coal Seam 401}

Figures 26-29 shows the pressure history, molar concentration change, cumulative production and injection of all gases and the injection/production flow rate at STP for Experiment VII conducted on the coal seam 401 Experiment VII was conducted on a vertical drill core from Poland and was intended to compare the effects of an alternate injection of a strong $\left(\mathrm{CO}_{2}\right)$ and weak $\left(\mathrm{N}_{2}\right)$ adsorbing gas. $\mathrm{N}_{2}$ has stripping properties when injected in coal seams. In order to avoid this effect the experiment was so planned that the $\mathrm{N}_{2}$ injection was done after 


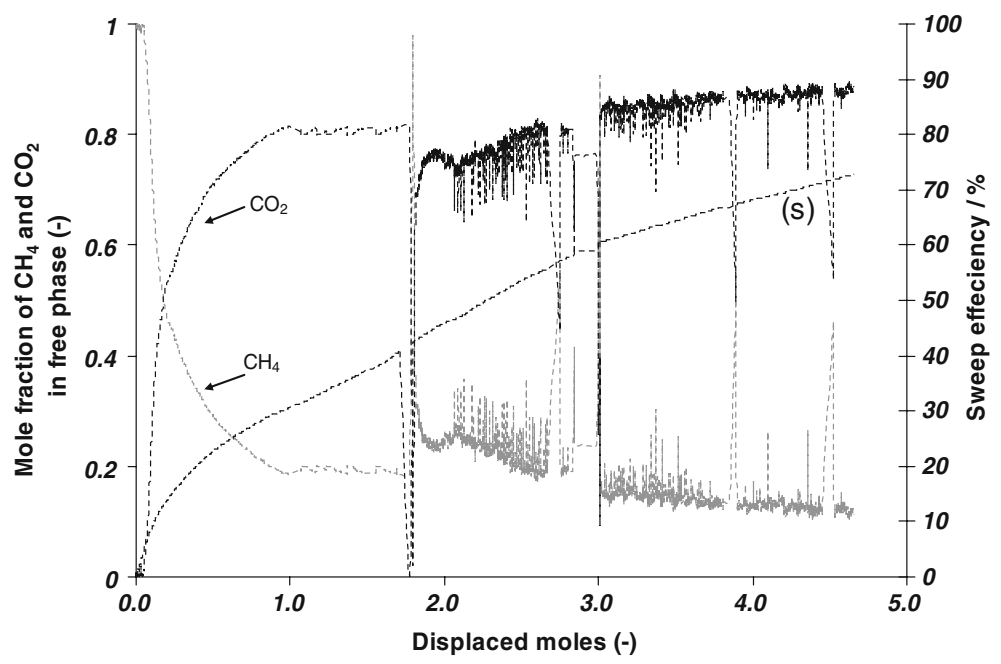

Fig. 23 Sweep efficiency $(s)$ and molar concentrations of the produced gas against displaced moles from Experiment VI (Brzeszcze, dry, $\mathrm{CO}_{2}$ injection at $0.5 \mathrm{ml} / \mathrm{h}$ ). The fluctuations on the migration data are because of the fact that the GC columns were not clean

Fig. 24 Cumulative production of all gases, and injection of $\mathrm{CO}_{2}$ from Experiment VI (Brzeszcze, dry, $\mathrm{CO}_{2}$ injection at $0.5 \mathrm{ml} / \mathrm{h}$ )

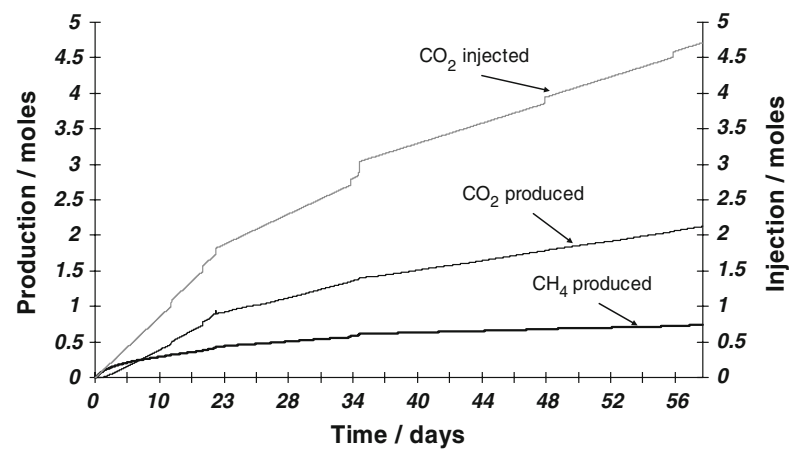

Fig. 25 Injection and production flow rate of gases for Experiment VI at STP

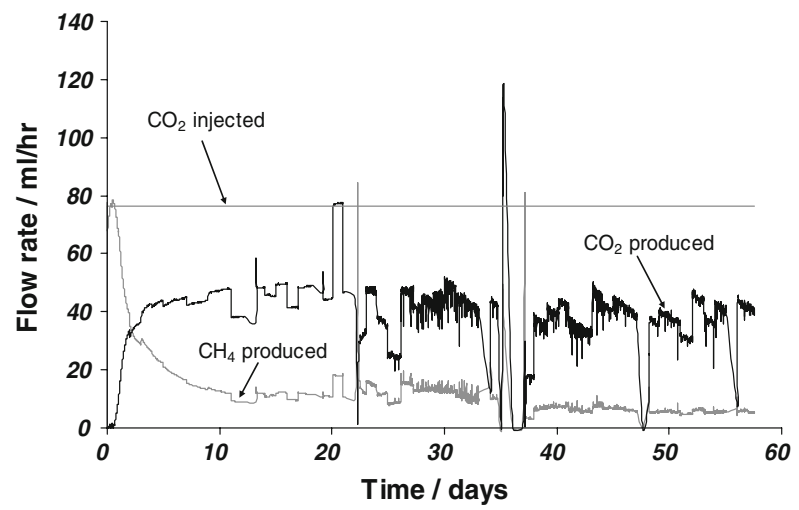


Table 6 The total, free, adsorbed and produced amount of carbon dioxide in the dry and wet Brzeszcze 501 flooding experiment

\begin{tabular}{lll}
\hline $\mathrm{CO}_{2}$ flooding (Brzeszcze 501) & Dry & Wet \\
\hline Total amount of $\mathrm{CO}_{2}$ injected (moles) & 4.7125 & 2.45 \\
Amount of adsorbed $\mathrm{CO}_{2}$ (moles) & 1.033 (max) & 0.423 (max) \\
Amount of free $\mathrm{CO}_{2}$ (moles) & 1.555 & 1.08 \\
Total amount of $\mathrm{CO}_{2}$ produced (moles) & 2.1245 & 0.947 \\
\hline
\end{tabular}

Table 7 Sweep efficiency, displaced moles and time of Experiment V and VI

\begin{tabular}{|c|c|c|c|c|c|c|}
\hline \multirow{2}{*}{$\begin{array}{l}\mathrm{CO}_{2} \text { flooding } \\
\text { (Brzeszcze } \\
501) \\
\end{array}$} & \multicolumn{2}{|l|}{$\mathrm{CO}_{2}=25 \%$} & \multicolumn{2}{|l|}{$\mathrm{CO}_{2}=50 \%$} & \multicolumn{2}{|l|}{$\mathrm{CO}_{2}=90 \%$} \\
\hline & Dry & Wet & Dry & Wet & Dry & Wet \\
\hline $\begin{array}{l}\text { Sweep } \\
\text { efficiency } \\
(\%)\end{array}$ & 8.83 & 9.2 & 12.97 & 13.5 & 72.62 & 25.4 \\
\hline $\begin{array}{l}\text { Displaced } \\
\text { moles } \\
(\text { mole/mole) }\end{array}$ & 0.1 & 0.22 & 0.18 & 0.29 & 4.63 & 1.36 \\
\hline $\begin{array}{l}\text { Time after } \\
\text { production } \\
\text { (s) }\end{array}$ & $1.08 \times 10^{5}$ & $2.1618 \times 10^{5}$ & $1.92 \times 10^{5}$ & $2.86 \times 10^{5}$ & $4.959 \times 10^{6}$ & $1.33 \times 10^{6}$ \\
\hline
\end{tabular}

one pump volume of $\mathrm{CO}_{2}$ injection. This was also meant to remove all the free methane from the system before nitrogen injection was initiated. The results of this experiment are summarized in Tables 8 and 9. Figure 27 shows the migration of $\mathrm{CH}_{4}, \mathrm{CO}_{2}$ and $\mathrm{N}_{2}$ through the core. As seen from other wet experiments the methane recovery of this experiment too is quite low (38\%) and the breakthrough is early too. The experiment started with the injection of one pump volume of $\mathrm{CO}_{2}$ (Fig. 27). At a displaced mole of 2.23, $\mathrm{N}_{2}$ injection started and after one pump volume, the $\mathrm{CO}_{2}$ injection was resumed at the corresponding displaced mole of 3.14. A sharp increase in $\mathrm{CH}_{4}$ production was observed alongside $\mathrm{N}_{2}$ breakthrough. This incremental $\mathrm{CH}_{4}$ production was quite consistent throughout the $\mathrm{N}_{2}$ production. With the injection of $\mathrm{CO}_{2}$ in a $\mathrm{CH}_{4}$ saturated coal, the partial pressures of $\mathrm{CH}_{4}$ in the free phase is reduced. This initiates the $\mathrm{CH}_{4}$ to sorb out of the coal and go into the free phase. Also at near critical conditions of $\mathrm{CO}_{2}$, the pressure, temperature and density behaviour, is very difficult. The possible cause of this effect is still unknown.

\subsection{Flue Gas Core Flood Experiments}

Figures 30-37 shows the pressure history, molar concentration change, cumulative production and injection of all gases and the injection/production flow rate at STP for the two experiments conducted on the Silezia coal with flue gas as the injectant. .An alternate injectant to enhance the production of methane is needed because of the higher separation costs of liquid $\mathrm{CO}_{2}$. Therefore, flooding experiments were performed with commercially available flue gas. The specifications of the flue gas is provided in Table 10. The absence of an equation of state for the flue gas makes data processing complex. Hence, an equation of state (EOS) for flue gas have been developed. This EOS calculates densities for the injected flue gas. The algorithm developed by National Institute of Standards and Technology (NIST) predicts the volumetric 
Fig. 26 Measured system pressure during Experiment VII (Seam 401, wet, $\mathrm{CO}_{2} / \mathrm{N}_{2}$ injection at $0.5 \mathrm{ml} / \mathrm{h}$ ). The average effective stress applied was 20 bars
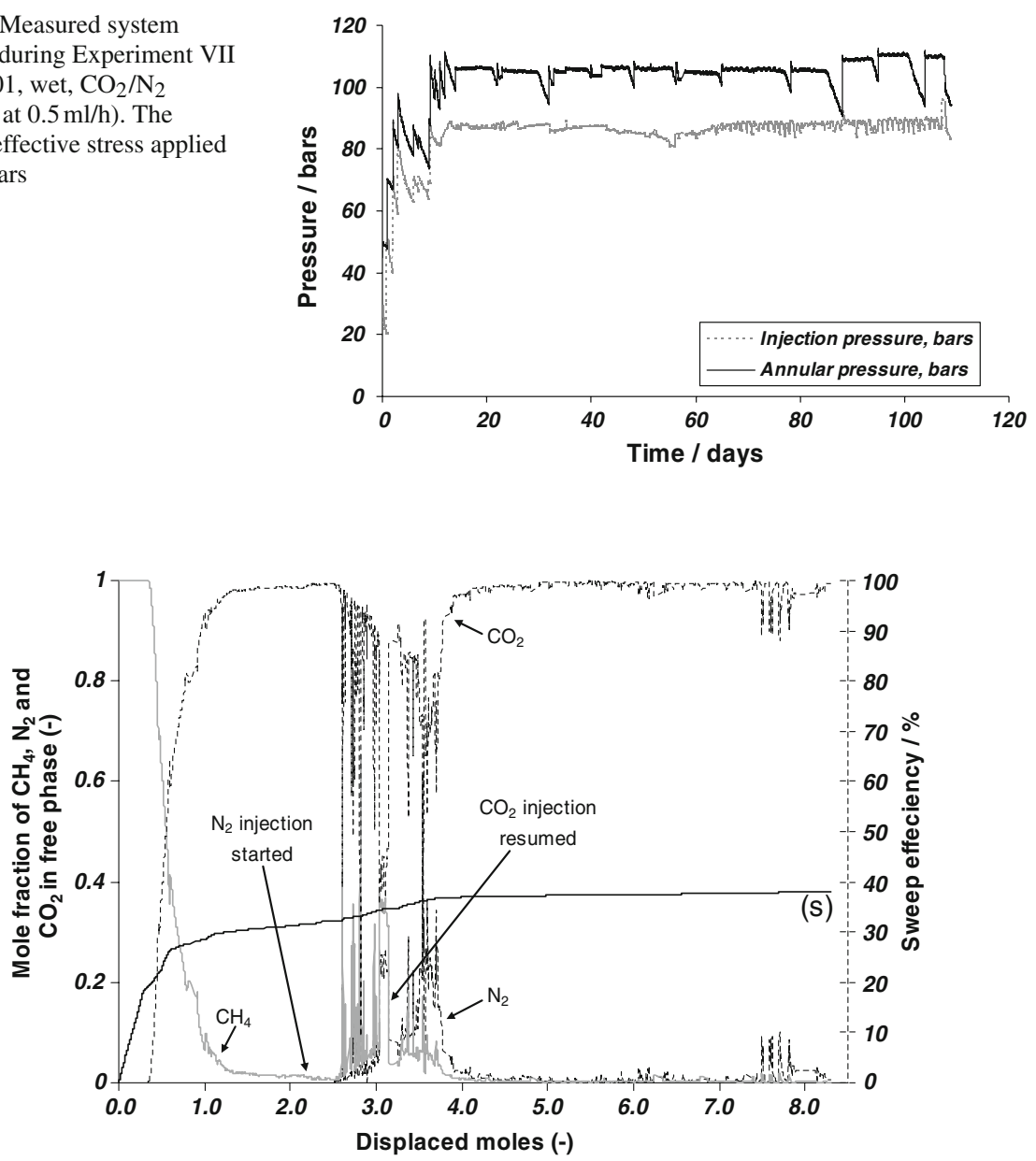

Fig. 27 Sweep efficiency $(s)$ and molar concentrations of the produced gas against displaced moles from Experiment VII (Seam 401, wet, $\mathrm{CO}_{2} / \mathrm{N}_{2}$ injection at $0.5 \mathrm{ml} / \mathrm{h}$ ). The alternate injection of a strong $\left(\mathrm{CO}_{2}\right)$ and weak $\left(\mathrm{N}_{2}\right)$ adsorbing gas result in the fluctuations of the concentration data between a displaced volume of 2.5 and 4

Fig. 28 Cumulative production of all gases, and injection of $\mathrm{CO}_{2}, \mathrm{~N}_{2}$ from Experiment VII (Seam 401, wet, $\mathrm{CO}_{2} / \mathrm{N}_{2}$ injection at $0.5 \mathrm{ml} / \mathrm{h}$ )

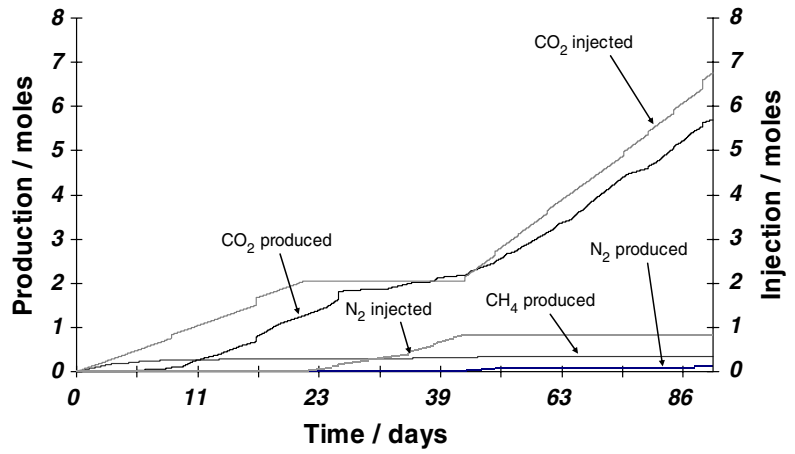




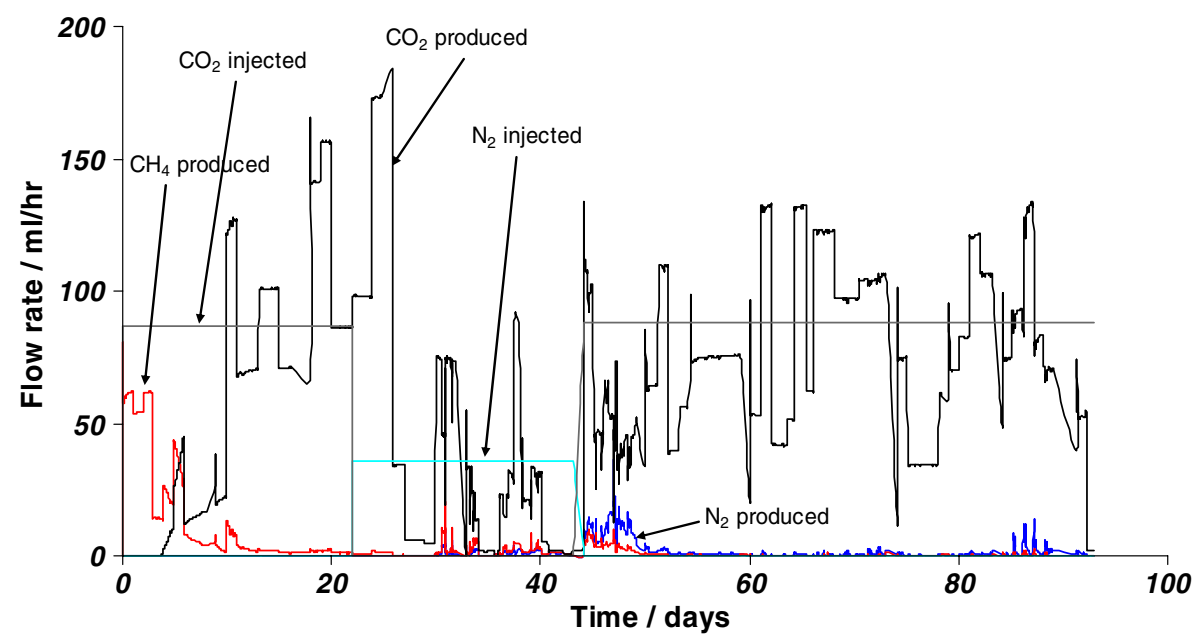

Fig. 29 Injection and production flow rate of gases for Experiment VII at STP

Table 8 The total, free, adsorbed and produced amount of carbon dioxide and nitrogen in sample Seam 401 (Vertical drill core from well MS3)
Total amount of $\mathrm{CO}_{2}$ injected (moles)

Total amount of $\mathrm{CO}_{2}$ produced (moles)

Total amount of $\mathrm{N}_{2}$ injected (moles)

6.758

5.68

0.8247

Total amount of $\mathrm{N}_{2}$ produced (moles)

Table 9 Sweep efficiency, displaced moles and time of Experiment VII

\begin{tabular}{llll}
\hline $\mathrm{CO}_{2} / \mathrm{N}_{2}$ flooding (Seam 401) & $\mathrm{CO}_{2}=1 \%$ & $\mathrm{CO}_{2}=50 \%$ & $\mathrm{CO}_{2}=90 \%$ \\
\hline Sweep efficiency (\%) & 19.59 & 24.93 & 28.4 \\
Displaced moles (mole/mole) & 0.364 & 0.553 & 0.956 \\
Time after production (s) & $3.09 \times 10^{5}$ & $4.698 \times 10^{5}$ & $8.12 \times 10^{6}$ \\
\hline
\end{tabular}

behaviour of a multi-component gas mixture in a single-phase region. The algorithm works in line with the Peng-Robinson EOS. It performs better than the Redlich-Kwong-Soave equation in all cases and shows greatest advantage in the prediction of liquid phase densities.

Results from the wet and dry flue gas experiments are summed in Tables 11, 12 and 13. The core details and the experimental conditions are provided in Table 2. Even though the pressures are same in both the dry and the wet experiments, the dry experiment has more amount of methane in there as compared to the wet. This is because of the fact, that in the wet experiment the coal core is made wet by injecting $100.1 \mathrm{~g}$ of water after saturating the core with $\mathrm{CH}_{4}$.

The migration data of the dry experiment is in Fig. 31. In the dry flooding experiment the amount of free methane is $0.7222 \mathrm{~mol}$, which is much more than the net amount of $\mathrm{CH}_{4}$ produced $(0.5003 \mathrm{~mol})$. In the dry experiment, with an injection rate of $1 \mathrm{ml} / \mathrm{h}$, hardly any adsorbed methane is produced. As compared to the wet experiment the dry one has more free methane. The free methane resides in the tubing system and the fracture porosity of the coal. The recovery factor of the dry experiment is $35.1 \%$. This recovery factor shows that with flue gas as an injectant, there is hardly no enhancement in recovery. The flue gas which 
Fig. 30 Measured system pressure during Experiment VIII (Silezia, dry, flue gas injection at $1.0 \mathrm{ml} / \mathrm{h}$ ). The average effective stress applied was 20 bars
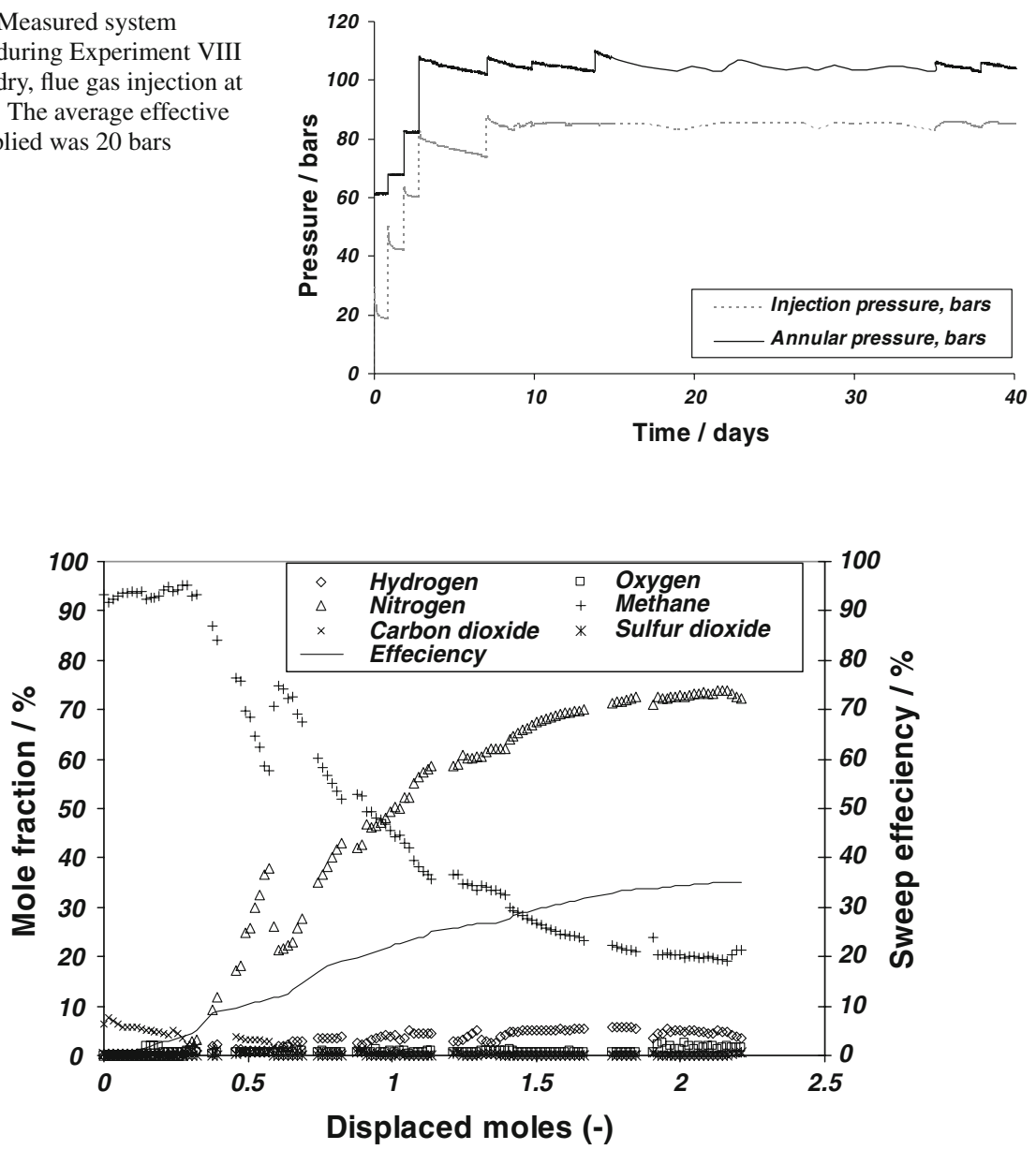

Fig. 31 Sweep efficiency and molar concentrations of the produced gas against displaced moles from Experiment VIII (Silezia, dry, flue gas injection at $1.0 \mathrm{ml} / \mathrm{h}$ )

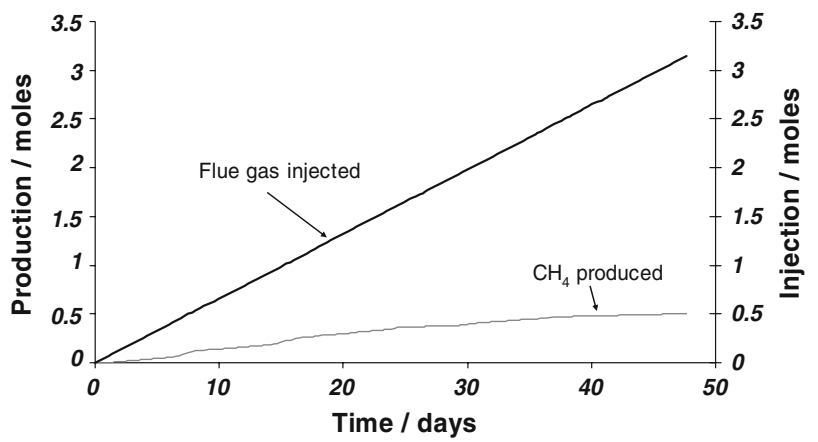

Fig. 32 Cumulative production of all gases, and injection of flue gas from Experiment VIII (Silezia, dry, flue gas injection at $1.0 \mathrm{ml} / \mathrm{h}$ ) 
Fig. 33 Injection and production flow rate of gases for Experiment VIII at STP
Fig. 34 Measured system pressure during Experiment IX (Silezia, wet, flue gas injection at $1.0 \mathrm{ml} / \mathrm{h}$ ). The average effective stress applied was 20 bars
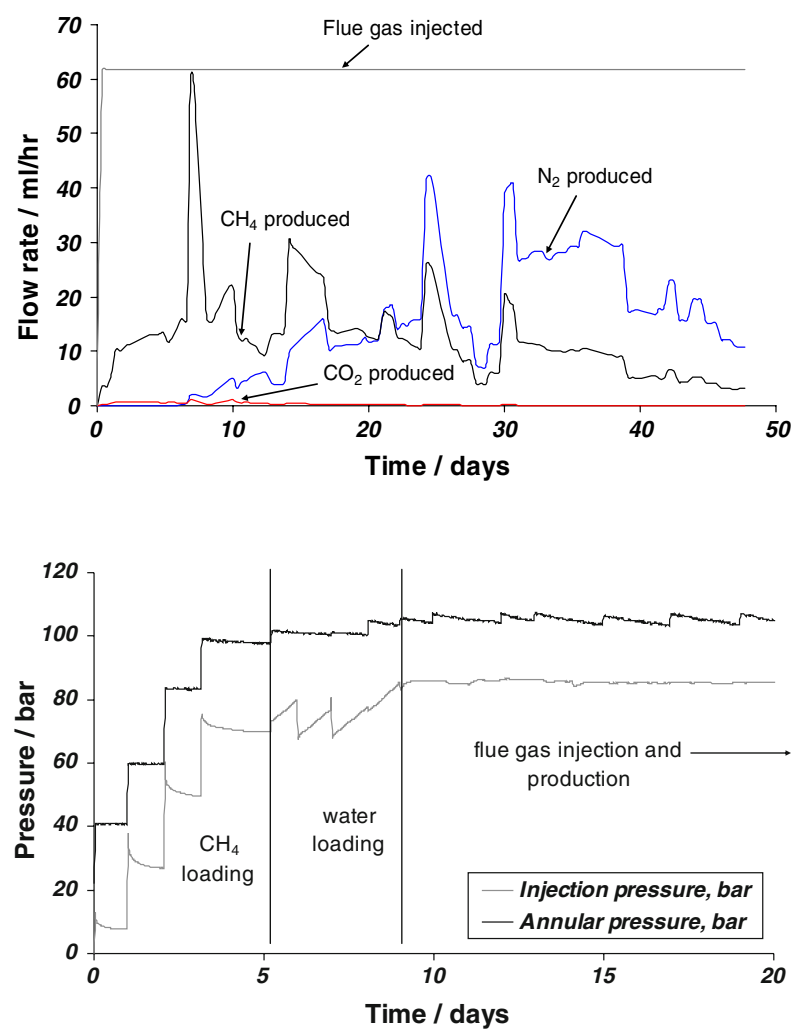

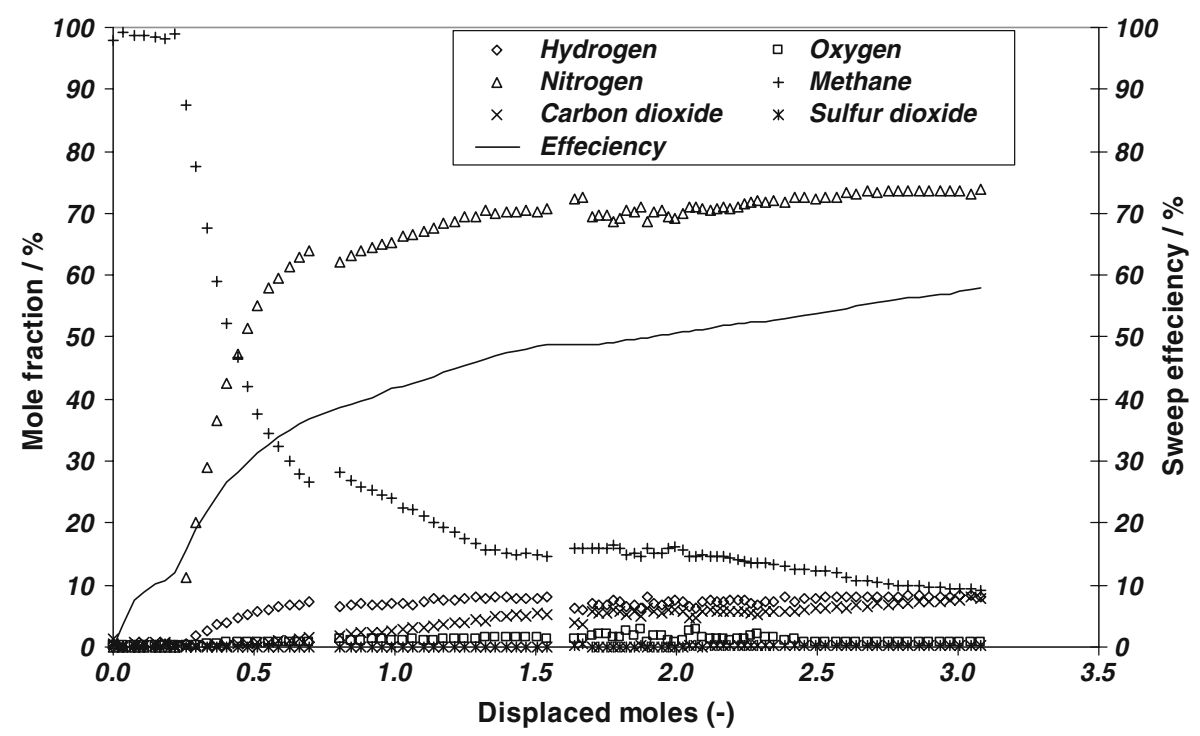

Fig. 35 Sweep efficiency and molar concentrations of the produced gas against displaced moles from Experiment IX (Silezia, wet, flue gas injection at $1.0 \mathrm{ml} / \mathrm{h}$ ) 
Fig. 36 Cumulative production of $\mathrm{CH}_{4}$, water and injection of flue gas from Experiment IX (Silezia, wet, flue gas injection at $1.0 \mathrm{ml} / \mathrm{h}$ )

Fig. 37 Injection and production flow rate of gases for Experiment IX at STP
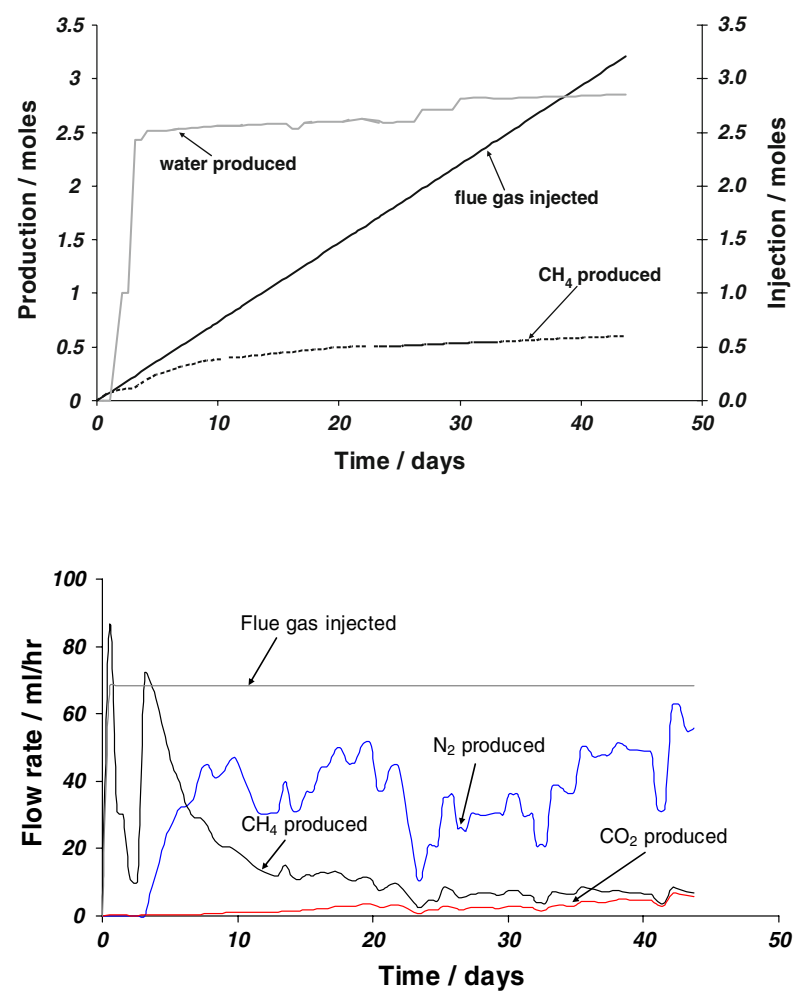

Table 10 Flue gas specification and used columns/carrier gas for chromatographic analysis and density determination

\begin{tabular}{llll}
\hline Component name & Gravimetric conc. $($ mole $\%)$ & Used column & Carrier gas \\
\hline $\mathrm{CO}_{2}$ & 10.9 & Porapack Q & $\mathrm{He}$ \\
$\mathrm{CO}$ & 0.01 & - & - \\
$\mathrm{H}_{2}$ & 9.0 & Mole-sieve & $\mathrm{Ar}$ \\
$\mathrm{CH}_{4}$ & 3.01 & Mole-sieve/porapack Q & $\mathrm{Ar} / \mathrm{He}$ \\
$\mathrm{O}_{2}$ & 3.00 & Mole-sieve & $\mathrm{Ar}$ \\
$\mathrm{SO}_{2}$ & 0.106 & - & - \\
$\mathrm{N}_{2}$ & 73.974 & Mole-sieve & $\mathrm{Ar}$ \\
\hline
\end{tabular}

Table 11 The total, free, adsorbed and produced amount of flue gas in sample Silesia 315 II

\begin{tabular}{lll}
\hline Flue flooding (Silesia 315 II) & Dry & Wet \\
\hline Total amount of flue gas injected (moles) & 3.15 & 3.24 \\
Amount of free flue gas (moles) & 0.7273 & 0.570 \\
Total amount of flue gas produced (moles) & 0.8684 & 1.9801
\end{tabular}


Table 12 Cumulative amount of each component injected and produced during the dry and wet flue flooding experiments

\begin{tabular}{|c|c|c|c|c|c|c|c|c|c|c|}
\hline & \multicolumn{2}{|l|}{$\mathrm{H}_{2}$} & \multicolumn{2}{|l|}{$\mathrm{O}_{2}$} & \multicolumn{2}{|l|}{$\mathrm{N}_{2}$} & \multicolumn{2}{|l|}{$\mathrm{CO}_{2}$} & \multicolumn{2}{|l|}{$\mathrm{SO}_{2}$} \\
\hline & Dry & Wet & Dry & Wet & Dry & Wet & Dry & Wet & Dry & Wet \\
\hline Moles injected & 0.29 & 0.30 & 0.095 & 0.10 & 2.34 & 2.44 & 0.35 & 0.36 & 0.003 & 0.004 \\
\hline Moles produced & 0.05 & 0.17 & 0.012 & 0.03 & 0.70 & 1.57 & 0.012 & 0.105 & 0.001 & 0.003 \\
\hline$\%$ Produced & 18.20 & 57.11 & 12.14 & 26.44 & 29.72 & 64.56 & 3.5 & 29.15 & 43.00 & 79.22 \\
\hline
\end{tabular}

Table 13 Sweep efficiency, displaced moles and time of the dry and wet flue flooding experiment

\begin{tabular}{|c|c|c|c|c|c|c|}
\hline \multirow{2}{*}{$\begin{array}{l}\text { Flue flooding } \\
\text { (Silesia } 315 \text { II) }\end{array}$} & \multicolumn{2}{|l|}{$\mathrm{N}_{2}=1 \%$} & \multicolumn{2}{|l|}{$\mathrm{N}_{2}=50 \%$} & \multicolumn{2}{|l|}{$\mathrm{N}_{2}=73.9 \%$} \\
\hline & Dry & Wet & Dry & Wet & Dry & Wet \\
\hline $\begin{array}{l}\text { Sweep efficiency } \\
(\%)\end{array}$ & 4.175 & 14.35 & 22.33 & 29.12 & 35.01 & 57.93 \\
\hline $\begin{array}{l}\text { Displaced moles } \\
(\mathrm{mole} / \mathrm{mole})\end{array}$ & 0.288 & 0.245 & 1.00 & 0.460 & 2.17 & 3.09 \\
\hline $\begin{array}{l}\text { Time after } \\
\text { production (s) }\end{array}$ & $5.37 \times 10^{5}$ & $2.99 \times 10^{5}$ & $1.87 \times 10^{6}$ & $5.63 \times 10^{5}$ & $4.04 \times 10^{6}$ & $3.78 \times 10^{6}$ \\
\hline
\end{tabular}

is primarily $\mathrm{N}_{2}$, races through the tubing system and is produced. When the thermo physical properties of $\mathrm{N}_{2}$ are compared with those of $\mathrm{CO}_{2}$, the $\mathrm{CO}_{2}$ has higher density and higher internal energy under reservoir conditions. The viscosity of $\mathrm{CO}_{2}$ and $\mathrm{N}_{2}$ does not differ much. The $\mathrm{CO}_{2}$ in the flue gas does get adsorbed on the surface of the coal but is unable to enhance the production of methane. Thus, as reported (Cui et al. 2003) $\mathrm{CO}_{2}$ has separate adsorption sites beside $\mathrm{CH}_{4}$.

In the wet experiment the methane saturation is done at a lower pressure (69.8 bar) compared to a dry experiment $(84.35$ bar $)$. After methane saturation the cell is filled up with $100.1 \mathrm{~g}$ of water which in turn brings the pressure up to 85.84 bar. Thereafter, the flue gas was injected at a rate of $1 \mathrm{ml} / \mathrm{h}$. The loading process is shown in Fig. 34. The migration data of the wet experiment is shown in Fig. 35. Water occupied a part of the free volume in the cell which was in the dry experiment completely occupied by the free methane. Consequently, the free methane volume in the wet experiment $(0.4095 \mathrm{~mol})$ is less than the free methane volume in the dry experiment $(0.7222 \mathrm{~mol})$. Based on this volume difference we may assume that since most of the water through the cleat system follow Darcy flow, it acts like a plug between the methane and carbon dioxide (Fig. 36). There is no possible physical reasoning behind this process. Modeling efforts might be able to answer this.

The discussion above implies that the experimental procedure used to inject water is not suitable. The injected water forms a water plug in the cleat system, instead of being uniformly distributed throughout the coal cleats and matrix. An example of water acting as a plug is shown in Fig. 36. As an alternative the coal core can be soaked with water, shortly evacuated and then saturated with methane.

\section{Conclusions}

With the injection of $\mathrm{CO}_{2}$, the partial pressure of $\mathrm{CH}_{4}$ in the free phase decreased, inducing the production of methane. Whether or not $\mathrm{CO}_{2}$ is preferentially replacing $\mathrm{CH}_{4}$ was not 
clear. The $\mathrm{CO}_{2}$ mass balance shows that the solubility of $\mathrm{CO}_{2}$ in coal is more pronounced than that for $\mathrm{CH}_{4}$. The term solubility is used, considering that coal has a highly cross linked macromolecular network. Moreover, the dry experiments indicate that the amount of desorbed $\mathrm{CH}_{4}$ is marginally greater than the desorption resulting from the reduction in partial pressures of methane. This was not observed in wet experiment. Consequently, under dry conditions, the incremental methane produced is likely due to the preferential desorption of methane in the presence of $\mathrm{CO}_{2}$. Thus moisture reduces $\mathrm{CO}_{2}$ selectivity drastically since it appears to block $\mathrm{CO}_{2}$ sorption sites.

The sweep efficiency of the two experiments (VIII and IX) with flue gas are less compared to the $\mathrm{CO}_{2}$ flooding experiments under similar conditions. There is hardly any production of adsorbed methane from the coal. The flue gas experiments, with $\mathrm{N}_{2}$ as the main constituent can be considered as a $\mathrm{N}_{2}$ stripping experiment. In comparison to the six different components in flue gas, $\mathrm{CO}_{2}$ was the most adsorbed species. Significant reduction in the $\mathrm{CO}_{2}$ concentration was measured in the product gas. A process of $\mathrm{CO}_{2}$ filtration seems promising. From the experiments it is clear, that on a pore scale $\mathrm{CO}_{2}$ is better adsorbed compared to $\mathrm{CH}_{4}$.

Comparison of the results for the Silesian Basin coal samples shows that moisture tends to reduce the preferential sorption of $\mathrm{CO}_{2}$. These effects are attributed to the affinity of both water and $\mathrm{CO}_{2}$ towards hydrophilic (e.g. hydroxylic, carbonylic, carboxylic) functional groups on the coal surface. These groups are more abundant in inertinite-rich coals (Brzeszcze coal) than in vitrinite-rich coals (Silezia coal) of similar rank. This gives rise to the assumption that inertinite and moisture content are the two controlling factors influencing the preferential adsorption behaviour of $\mathrm{CO}_{2} / \mathrm{CH}_{4}$ gas mixtures in coal of similar maturity.

Due to the lack of exact duplicate experiments and since it is a first hand investigation on coal cores/gas/liquid systems, experiments have been compared qualitatively. All these experiments should be used to understand processes under those specific experimental condition. The stage for comparison can only be set when there is ample data available by repeating these experiments, so as to get a consistency in the parameters reported.

Pure component and mixed gas sorption isotherms should only be used for qualitative purposes as it is noted that variation in grain sizes has profound effect on the magnitude of any preferential sorption behaviour. The degree of preference for $\mathrm{CO}_{2}$ sorption evidently increases with increasing inertinite and ash content, both of which increase with decreasing grain size and vice versa.

\section{Appendix A-Void Volume Measurements}

For better understanding and comparison of the results, a schematic of the set-up is shown in Fig. 1. The whole set-up is divided into four parts. These volumes are mostly inherent in the set-up, enclosed by two valves. Volume measurements have been conducted by helium expansion. All volumes reported below are at standard temperature and pressure (STP).

Starting from left to right (Fig. 1), the first part of the volume includes the volume of the pump plus a small portion of the tubing leading out of the pump to the injection side. This volume terminates at valve 1 . Valve 1 is an air actuated valve which is opened only when the pump is injecting. The volume of this portion is $283.02 \mathrm{ml}$, out of which the syringe pump itself has a volume of $266.50 \mathrm{ml}$. Out of the total $283.02 \mathrm{ml}$, only $266.50 \mathrm{ml}$ can be displaced during the course of the experiment. Thus, the volume enclosed within part 1 does not have any contribution towards the absolute free volume of the set-up. 
Second part is the part of the tubing enclosed between valve 1 and valve 2 . This part has a volume of $44.04 \mathrm{ml}$. This volume does contribute towards the absolute free volume of the set-up.

The third part is the volume between valve 2 and valve 3 . This comprise of the volume of the tubing in and out of the pressure cell, volume of the tubing leading to the pressure difference measurement over the core and the porous volume of the coal core itself. This part measures different volumes with different coal samples. For experiment I it is $137.97 \mathrm{ml}$. Out of this, the porous volume of the core is $63.35 \mathrm{ml}$. As can be seen from the schematic, the volume of the tubing leading to the pressure difference measurement is static. The tubing diameter (OD) of this part is $3.14 \mathrm{~mm}$. This total tubing volume was approximately calculated to be $5 \mathrm{ml}$. The only way this static volume interacts with the flow stream is by the process of diffusion. The diffusion rates being very low, this volume is neglected. Apart from the porous coal the two end plates attached to the core itself contribute the most towards the volume of this part. The end plates and the tubing volume cannot be eliminated as they are vital in the construction of the set up. Subtracting the porous volume of the coal $(63.35 \mathrm{ml})$ from the total free volume, gives us the tubing volume $(74.62 \mathrm{ml})$. Likewise for Experiments II and VII, the total volume for this part is $108.44 \mathrm{ml}$ and $142.28 \mathrm{ml}$, respectively. For experiments III, IV, VIII and IX this volume is $135.48 \mathrm{ml}$ and for experiments V and VI the volume is $132.01 \mathrm{ml}$.

The fourth part is the volume between valve 3 and the back pressure valve. This part has a volume of $46.725 \mathrm{ml}$ and does contribute to the free volume of the set up.

When the core is set on production alongside injection, the tubing volume that is on the production side core is set to be displaced first by the injected fluid. This volume is $84.03 \mathrm{ml}$ in total. For example, when $\mathrm{CO}_{2} /$ flue gas is injected at a rate of $1 \mathrm{ml} / \mathrm{h}$ and assuming that equilibrium was attained, it would take around 3.5 days to flush out $84.03 \mathrm{ml}$. Since the pressure in the cell remained constant, it is a fair assumption that the core produced at the same rate as that of the injection. Thus the first 3 to 4 days of production data will have the information related to the void volume preceding the coal core.

\section{Appendix B-Single Component Sorption Isotherms}

In view of the core flooding experiments, the $\mathrm{CO}_{2}$ and $\mathrm{CH}_{4}$ sorption isotherms on the Belgian and Polish coal samples used in the aforesaid study were measured. These experiments also demonstrate the influence of moisture on high temperature $\mathrm{CO}_{2}$ and $\mathrm{CH}_{4}$ sorption isotherms for natural coals. The three Carboniferous coal samples studied, originated from coal mining areas in Belgium and Poland. The sorption experiments in the dry and moisture equilibrated state reported here were performed on two coals (Silezia and Brzeszcze) from the Silesian basin, Poland. These samples were provided by the Polish Central Mining Institute, Katowice, in the context of the EU Recopol project. The Beringen coal sample was obtained from a mine in Belgium and only dry absolute sorption isotherms were generated for both $\mathrm{CO}_{2}$ and $\mathrm{CH}_{4}$ at $45^{\circ} \mathrm{C}$. The petrographic properties of the coal samples used in this study are listed in Table 1.

For the determination of $\mathrm{CO}_{2}$ and $\mathrm{CH}_{4}$ excess sorption isotherms, the same volumetric method was used as described by Krooss et al. (2002). Several modifications in the experimental set-up and the procedure have resulted in a significant improvement of the quality of the sorption isotherms: (i) While in the previous set-up the reference cell (including the pressure transducer) and the measuring cell were kept in separate compartments at different temperatures the entire system was now placed into one thermostatic chamber. This modifi- 
cation ensured the reduction of temperature-related effects on the measurements. (ii) Even minor admixtures of other gases result in significant effects on the Equation of State of $\mathrm{CO}_{2}$. It became evident that small amounts of helium (He) from the preceding assessment of void volume may have remained in the tubing system in some instances. Therefore, specific attention was given to the thorough removal of helium from the system prior to each sorption experiment. (iii) The volumetric method involves two compression/expansion steps: (a) charging a calibrated reference volume with gas and (b) expanding the gas from the reference volume to the measuring cell. Both steps are associated with considerable temperature effects. Sufficient time was always allowed for temperature/pressure equilibration, and the pressure equilibration carefully monitored for all the experiments.

Excess sorption isotherms are expressed in mass ( $\mathrm{g}$ or $\mathrm{kg}$ ) or amount of substance (mol, $\mathrm{mmol}$ ) sorbate per unit mass ( $\mathrm{g}$ or $\mathrm{kg}$ ) of sorbent. In the classical Langmuir approach for lowpressure sorption the volume of the sorbed phase is neglected. For high-pressure sorption of the volume of the adsorbed phase is not negligible. For a sorptive/sorbent system consisting of two fluid phases (gas or super critical phase and sorbed phase) and a solid sorbent, the excess sorption is defined as follows:

$$
m_{\text {excess }}=V_{\text {sorbed }} \cdot \rho_{\text {sorbed }}+\left(V_{\text {gas }}-V_{\text {void }}\right) \cdot \rho_{\text {gas }} .
$$

Here $\rho$ denotes the density of the fluid phases and $V_{\text {void }}$ denotes the total volume occupied by the sorbed phase ( $\left.V_{\text {sorbed }}\right)$ and the free gas $\left(V_{\text {gas }}\right)$ :

$$
V_{\text {void }}=V_{\text {sorbed }}+V_{\text {gas }} \text {. }
$$

All volumes $(V)$ and masses $(m)$ are normalized to the mass of sorbent and the sorbent is assumed as volume-invariant (non-swelling). Combining yields:

$$
m_{\text {excess }}=V_{\text {sorbed }} \cdot\left(\rho_{\text {sorbed }}-\rho_{\text {gas }}\right) \Longleftrightarrow m_{\text {excess }}=m_{\text {sorbed }} \cdot\left(1-\frac{\rho_{\text {gas }}}{\rho_{\text {sorbed }}}\right) .
$$

In the aforesaid equation the excess sorbed mass (i.e. the mass accommodated in the system in excess of the hypothetical non-sorption case) is a function of the ratio of gas phase and sorbed phase density and of the mass of the sorbed phase. The density of gaseous and super critical $\mathrm{CO}_{2}$ is well known as a function of pressure and temperature. In this study the EOS by Span and Wagner (1996) was used. The density of the sorbed phase is less well known but can be estimated with some reasonable assumptions. The density of liquid $\mathrm{CO}_{2}$ ranges between 1,000 and $1,150 \mathrm{~kg} / \mathrm{m}^{3}$. For simplicity a fixed value for the sorbed phase density $\left(\rho_{\text {sorbed }}\right)$ of $1,028 \mathrm{~kg} / \mathrm{m}^{3}$ was assumed.

While Fig. 38 shows the absolute sorption isotherms for dry Beringen 770 coal, Figs. 39 and 40 shows the $\mathrm{CO}_{2}$ and $\mathrm{CH}_{4}$ excess sorption isotherms measured on the dry and wet Silezia 315 and Brzeszcze coal samples at $45^{\circ} \mathrm{C}$. While the absolute sorption isotherms (Fig. 38) are presented in units of Scf/ton, the excess sorption isotherms (Figs. 39 and 40) are presented in $\mathrm{mmol} / \mathrm{g}$ coal $\left(1 \mathrm{Std} . \mathrm{m}^{3} \mathrm{CO}_{2}\left(1 \mathrm{~atm}, 15^{\circ} \mathrm{C}\right)=42.29 \mathrm{~mol}\right)$.

The $\mathrm{CO}_{2}$ isotherms for the Belgian and Polish coals measured in this study, show that an optimum pressure exists beyond which storage becomes less effective. The repeatedly confirmed shape of the $\mathrm{CO}_{2}$ excess sorption isotherms show a decline in excess sorption with increasing pressure. It can be shown, however, that this effect is related to the increase in sorbed-phase volume with pressure and is essentially controlled by the variation of the ratio of the density of free (super critical) and adsorbed $\mathrm{CO}_{2}$. In many instances the increase in sorbed phase volume cannot account completely for the observed effects so that swelling 


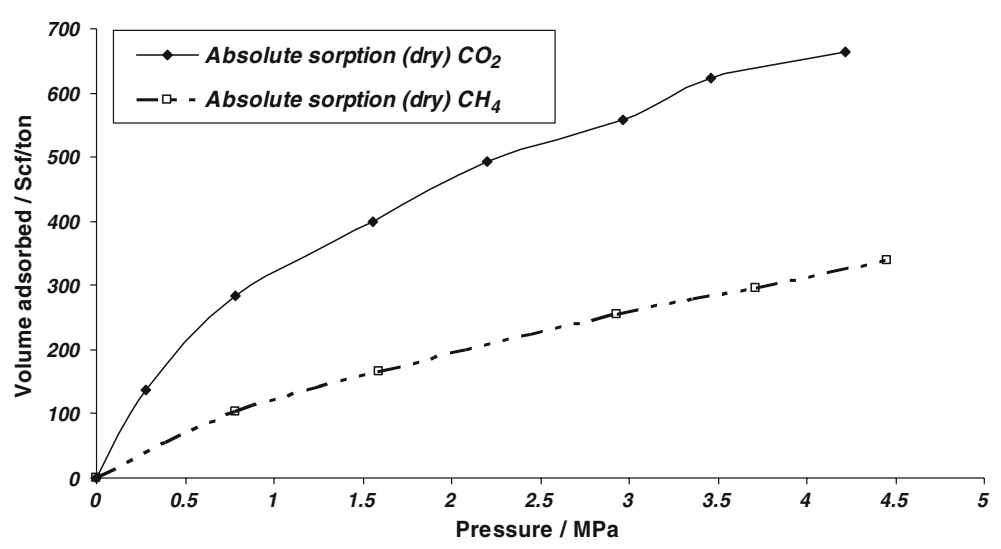

Fig. 38 Comparison of $45^{\circ} \mathrm{C} \mathrm{CO}_{2}$ and $\mathrm{CH}_{4}$ absolute sorption isotherms on dry Beringen 770 coal

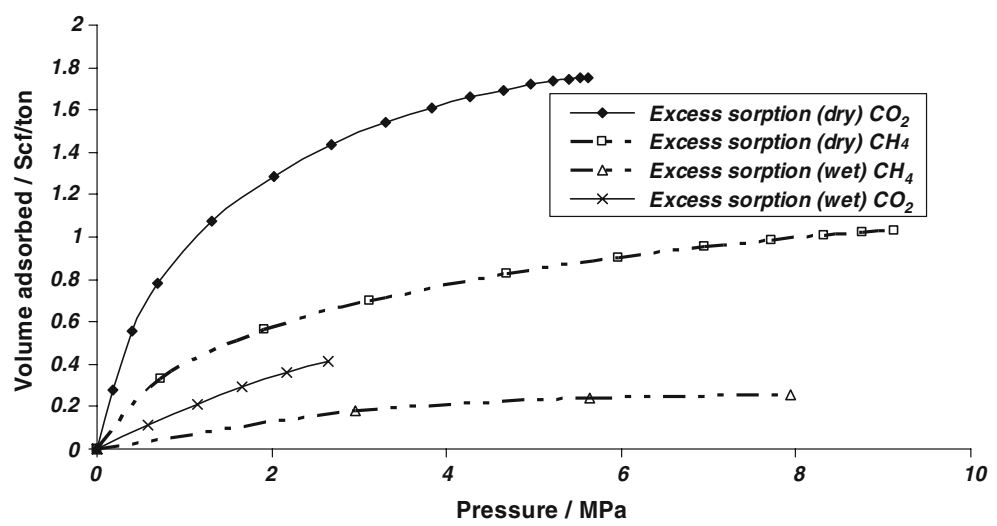

Fig. 39 Comparison of $45^{\circ} \mathrm{C} \mathrm{CO}_{2}$ and $\mathrm{CH}_{4}$ excess sorption isotherms on wet and dry Silezia 315 coal (size fraction $>2 \mathrm{~mm}$ )

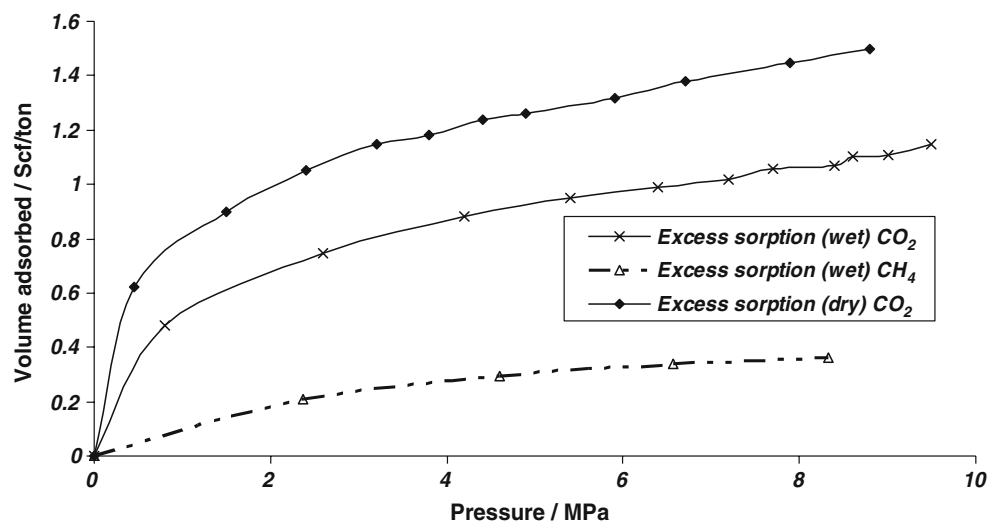

Fig. 40 Comparison of $45^{\circ} \mathrm{C} \mathrm{CO}_{2}$ and $\mathrm{CH}_{4}$ excess sorption isotherms on wet and dry Brzeszcze coal (size fraction $<0.2 \mathrm{~mm}$ ). The dry sorption experiment with $\mathrm{CH}_{4}$ was not conducted 
of the coal matrix must be considered as another contributing factor. This issue is under investigation and thus the data beyond the point of initiation of this effect has not been presented. Additional single component isotherms for the same Polish samples (dry and moist) were conducted by Siemons and Busch (2007).

Acknowledgements This work was funded by the EU funded $\mathrm{CO}_{2}$ sequestration project "RECOPOL", Dutch "CATO" programme and NWO-NOVEM. At the very onset, we would like to thank Prof. Harpalani and Dr. Hans Bruining for their valuable input. We would like to extend our gratitude once again to both of them for being patient, and inspiring us to walk on this path, which was arduous at times. My special thanks to Henk van Asten and Leo Vogt for their technical support. The experimental work would not have been possible without their help.

Open Access This article is distributed under the terms of the Creative Commons Attribution Noncommercial License which permits any noncommercial use, distribution, and reproduction in any medium, provided the original author(s) and source are credited.

\section{References}

Bertheux, W.: Enhanced $\mathrm{CBM}$ production by $\mathrm{CO}_{2}$-injection in water saturated coal: experiments, image analysis and simulations, M.Sc. Thesis, Delft University of Technology, The Netherlands (2000)

Busch, A., Gensterblum, Y., Krooss, B.M., Littke, R.: Methane and carbon dioxide adsorption-diffusion experiments on coal: upscaling and modelling. Int. J. Coal Geol. 60, 151-168 (2004)

Busch, A., Gensterblum, Y., Krooss, B.M., Siemons, N.: Investigation of high-pressure selective adsorption/desorption behaviour of $\mathrm{CO}_{2}$ and $\mathrm{CH}_{4}$ on coals: An experimental study. Int. J. Coal Geol. 66, 53-68 (2006)

Clarkson, C.R., Bustin, R.M.: The effect of pore structure and gas pressure upon the transport properties of coal: a laboratory and modeling study. 2. Adsorption rate modeling. Fuel 78(11), 1345 (1999)

Cui, X., Bustin, R.M., Dipple, G.: Selective transport of $\mathrm{CO}_{2}, \mathrm{CH}_{4}$, and $\mathrm{N}_{2}$ in coals: insights from modeling of experimental gas adsorption data. Fuel 83, 293-303 (2003)

Krooss, B.M., van Bergen, F., Gensterblum, Y., Siemons, N., Pagnier, H.J.M., David, P.: High-pressure methane and carbon dioxide adsorption on dry and moisture-equilibrated Pennsylvanian coal. Int. J. Coal Geol. 51, 69-92 (2002)

Mazumder, S., Wolf, K-H.A.A.: $\mathrm{CO}_{2}$ Injection for enhanced $\mathrm{CH}_{4}$ production from coal seams: laboratory experiments and simulations. In: Proceedings of Petrotech, New Delhi, vol. 329 (2003)

Mazumder, S., Van Hemert, P., Bruining, J., Wolf, K.-H.A.A.: A Preliminary numerical model of $\mathrm{CO}_{2}$ sequestration in coal for improved coalbed methane production. In: Proceedings of the International Coalbed Methane Symposium, Tuscaloosa, U.S.A., vol. 0331 (2003)

Reznik, A.A., Singh, P.K., Foley, W.L.: An analysis of the effect of $\mathrm{CO}_{2}$ injection on the recovery of in-situ methane from bituminous coal: an experimental simulation. SPE 10822 (1984)

Shi, J.Q., Durucan, S.: A bidisperse pore diffusion model for methane displacement desorption in coal by $\mathrm{CO}_{2}$ injection. Fuel 82, 1219 (2003)

Siemons, N., Busch, A.: Measurement and interpretation of supercritical $\mathrm{CO}_{2}$ sorption on various coals. Int. J. Coal Geol. 69, 229-242 (2007)

Span, R., Wagner, W.: A new equation of state for carbondioxide covering the fluid region from the triple-point temperature to 1,100 K at pressures upto $800 \mathrm{MPa}$. J. Phys. Chem. Ref. Data 25(6), 1509-1596 (1996)

Wolf, L, K.H.A.A., Hijman, R., Barzandji, O., Bruining, J.: Laboratory experiments and simulations on the environmentally friendly improvement of CBM-production by carbon dioxide injection. In: Proc. Int. Coalbed Methane Symp., Tuscaloosa, Alabama, pp. 279-290 (1999a)

Wolf, K.H.A.A., Hijman, R., Barzandji, O., Bruining, J.: Feasibility study on $\mathrm{CO}_{2}$-sequestration and CBMproduction. Novem Report on modeling work, economics and related lab experiments, Contr.nr. 234130/9001, TU Delft, Delft (1999b)

Wolf, K.H.A.A., Barzandji, O., Bertheux, W., Bruining, J.: $\mathrm{CO}_{2}$-sequestration in The Netherlands. $\mathrm{CO}_{2}$ injection and $\mathrm{CH}_{4}$-production as related to the Dutch situation: laboratory experiments and field simulation. In: Proc. 5th Int. Conf. on Greenhouse Gas Control Technologies, Cairns, Australia, pp. 1-6 (2000) 